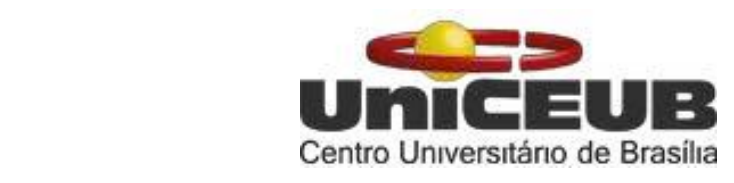

CENTRO UNIVERSITÁRIO DE BRASÍLIA - UniCEUB

PROGRAMA DE INICIAÇÃO CIENTÍFICA

\author{
NATÁLIA ARAUJO COSTA
}

ANÁLISE DE ANTÍGENOS DE SUPERFÍCIE DO VÍRUS DA HEPATITE B (HBSAG) COMO ESTRATÉGIA PROMISSORA PARA FINS BIOMÉDICOS.

BRASÍLIA

2020 


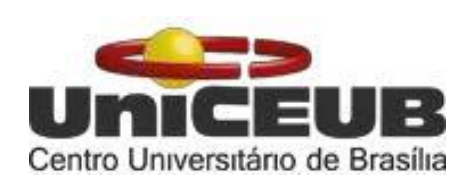

NATÁLIA ARAUJO COSTA

ANÁLISE DE ANTÍGENOS DE SUPERFÍCIE DO VÍRUS DA HEPATITE B (HBSAG) COMO ESTRATÉGIA PROMISSORA PARA FINS BIOMÉDICOS.

\author{
Relatório final de pesquisa de Iniciação Científica \\ apresentado à Assessoria de Pós-Graduação e \\ Pesquisa.
}

Orientação: Anabele Azevedo Lima

\title{
BRASÍLIA
}


"Não sabendo que era impossível, ele foi lá e fez." Jean Cocteau 


\section{ANÁLISE DE ANTÍGENOS DE SUPERFÍCIE DO VÍRUS DA HEPATITE B (HBSAG) COMO ESTRATÉGIA PROMISSORA PARA FINS BIOMÉDICOS}

INTRODUÇÃO: O vírus da Hepatite B (HBV) é um membro da família de vírus chamada Hepadnaviridae, caracterizado pela presença de DNA envelopado e capacidade de infectar as células hepáticas. Esse vírus infecta mamíferos e se replica nos hepatócitos, podendo evoluir em termos patológicos. De acordo com o Ministério da Saúde, no período de 1999 a 2015 foram notificados em todo o Brasil, 514.678 casos confirmados de Hepatite virais, caracterizando um problema de saúde pública. Pesquisas na área da virologia e produção biotecnológica têm sido muito utilizado para expressão de genes heterólogos em células de inseto, como por exemplo, o modelo eucarioto de expressão utilizando Baculovírus, inúmeras proteínas de importância médica e econômica foram expressas em níveis elevados aplicando esse sistema. Sendo assim, o presente trabalho visou analisar a expressão do antígeno de superfície HBsAg fusionado à proteína poliedrina, produzida pelo Baculovírus, uma vez que o HBsAg tem um papel fundamental no diagnóstico e prevenção da Hepatite $B$, por ser um antígeno marcador sorológico indicativo de infecção pelo HBV, cem como, o único componente da vacina contra o HBV, e assim, analisar possíveis reações cruzadas entre os diferentes vírus que causam hepatite. Atualmente, não existem indústrias ou empresas nacionais que produzam em larga escala o $\mathrm{HBsAg}$, necessitando importar vacinas e kits para diagnóstico. METODOLOGIA: Foi realizado quantificação de proteínas com QuantiT, teste comercial para dosagem de proteínas, e foram realizados testes sorológicos imunoenzimáticos, o ELISA (Enzyme-linked Immunosorbent Assay) indireto, método que se baseia na interação antígeno-anticorpo, utilizando o antígeno HBsAg fusionado a poliedrina (proteína recombinante) previamente construído. RESULTADOS: Foram realizados dois testes pelo método ELISA, os resultados foram obtidos a partir do soro de pacientes que tiveram contato com os vírus da Hepatite $B$, Hepatite $C$ e Citomegalovírus (CMV) em relação ao antígeno construído pelo sistema do Baculovírus, foram inconclusivos, o segundo teste foi realizada com amostras doadas pelo LACEN-DF positivas para hepatite $B$, porém o soro era positivo para outros patologias, como hepatite $A$ e hepatite $A$, sendo necessário realizar novos testes para ter um intervalo de confiança maior em relação ao teste. DISCUSSÃO/CONCLUSÃO: Portanto, há a necessidade de realizar mais testes sorológicos para verificar a veracidade do experimento e validá-lo estatisticamente. Contudo, sabemos que as hepatites virais são um grave problema de saúde pública no Brasil e no mundo, e necessitam de mais pesquisas, visando melhorar as formas de prevenção, diagnóstico e tratamento.

Palavras-Chave: Baculovírus. Vacina. Sistema de expressão. 


\section{SUMÁRIO}

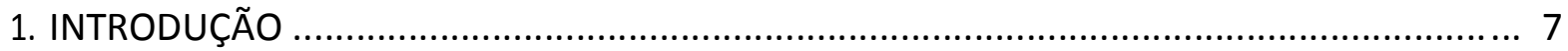

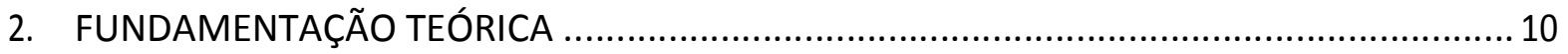

2.1 O vírus da Hepatite $B$ e sua partícula viral ............................................................. 10

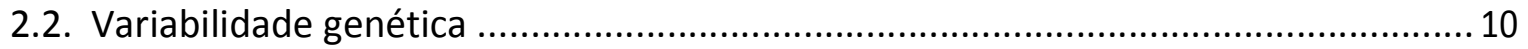

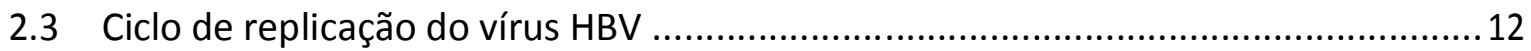

2.4 História da doença associada a infecção pelo vírus HBV e diagnóstico laboratorial ...13

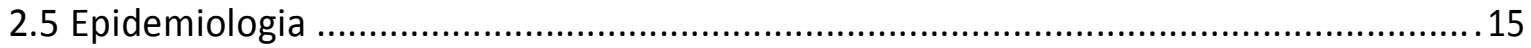

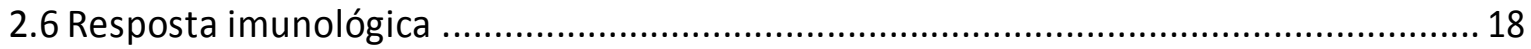

2.7 Diagnóstico imunológico e molecular......................................................................... 19

2.8 Sistema de expressão em baculovírus utilizando células de inseto para expressão do

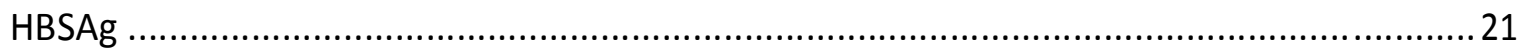

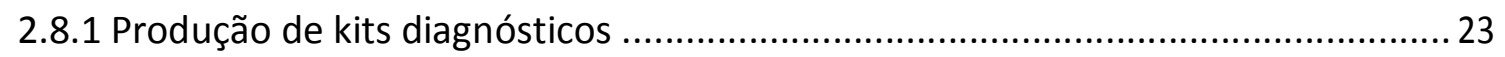

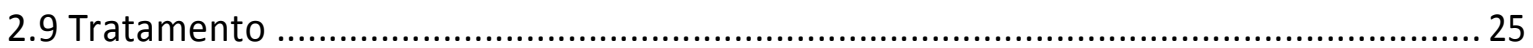

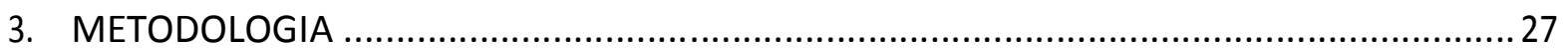

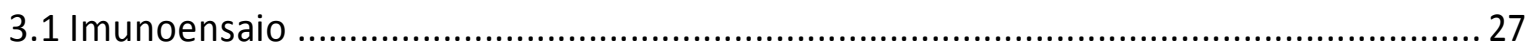

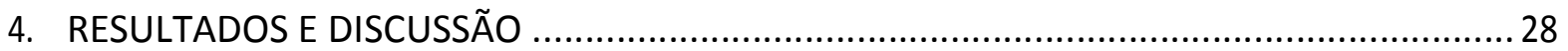

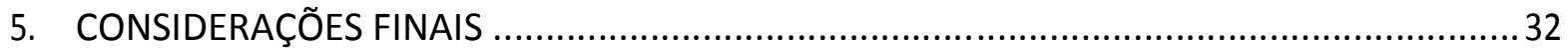

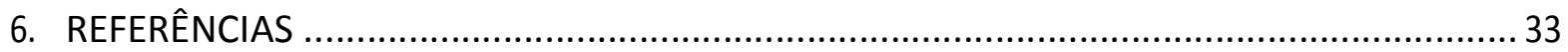




\section{INTRODUÇÃO}

No século IV a.C, Hipócrates considerado o "pai da medicina", obteve as primeiras referências quanto a casos epidêmicos de icterícia, onde seus escritos revelavam a possibilidade da epidemia ter origem infecciosa, o fígado como principal órgão afetado e com tendência a cronificação. O termo hepatite foi introduzido pela primeira vez por Bianchi no século XVIII, porém foi no final dos anos trinta que houve a descoberta da sua forma de transmissão, tendo como principal a inoculação parenteral a partir de soro humano (FONSECA, 2010).

Na década de 1960, Blumberg pesquisando proteínas no sangue observou a presença de um antígeno, no soro de um paciente australiano, denominando "antígeno Austrália", hoje conhecido como antígeno de superfície do vírus da hepatite B (HBsAg). Desde então, os avanços tecnológicos e o aumento no número de pesquisas científicas possibilitaram a descoberta de diferentes vírus capazes de causar hepatites na espécie humana (BRASIL, 2014).

Atualmente, cinco diferentes vírus são reconhecidos como agentes etiológicos para a hepatite viral, são eles: hepatite A (HAV), hepatite B (HBV), hepatite C (HCV), hepatite D ou Delta (HDV) e hepatite E (HEV). Embora possuam características diferentes quanto à sua estrutura molecular, classificação e genoma, os cinco agentes têm tropismo primário pelo tecido hepático, responsável por causar processos inflamatórios, agudos ou crônicos, onde na fase inicial da doença, pode-se apresentar sintomatologias comuns, como náuseas, vômitos, dores de cabeça, mal-estar e perda de apetite. Na fase ictérica, pode-se apresentar colúria, acolia e alterações na função hepática (HOUGHTON, 1996).

As hepatites A e E têm como principal via de contágio, fecal-oral ou por meio de águas e alimentos contaminados, que podem resultar em uma hepatite aguda benigna. $\mathrm{A}$ disseminação dos dois tipos de vírus está diretamente relacionada com a qualidade do saneamento básico. O HBV tem como transmissão a via parental, principalmente por via sexual, sendo considerada uma infecção sexualmente transmissível (IST), existe também a transmissão vertical, passada da mãe para o filho durante o parto. A hepatite B pode evoluir para uma hepatite crônica, trazendo complicações como cirroses ou tumores. Segundo a Secretaria de Vigilância em Saúde, aproximadamente 5\% dos pacientes evoluem para uma cronificação da doença e cerca de $70 \%$ de recém-nascidos contaminados por transmissão 
vertical correm risco de cronificação. A hepatite $\mathrm{C}$ ocorre principalmente por via parenteral e assim como o HBV pode evoluir para uma hepatite crônica, já a transmissão por relações sexuais é pouco frequente, menos de $1 \%$. A hepatite $D$ ou delta é um vírus satélite do HBV que necessita do HBsAg para realizar sua replicação e por isso possui os mesmos mecanismos de transmissão que o HBV. Por apresentar diversas etiologias, características, vias de transmissões distintas e possuir alto risco epidêmico, as hepatites virais são consideradas preocupantes em âmbito global (BRASIL, 2008).

As hepatites virais são responsáveis por cerca de 1,4 milhão de óbitos anualmente em todo o mundo. No Brasil, entre os anos de 2003 e 2007, a taxa de incidência de hepatite A era superior à das demais etiologias (B, C e D), porém, após 2007, apresentou uma queda significativa, atingindo 0,6/100 mil habitantes em 2016. Em contrapartida, nesse mesmo período, as taxas das hepatites B e C apresentaram um considerável aumento. Enquanto, as menores taxas são encontradas para a hepatite $D$, que se mantiveram constantes em todo o período. No período de 1999 a 2016, foram notificados mais de duzentos mil casos confirmados no de hepatite B no Brasil. Desde 1999, ano em que se iniciaram as notificações compulsórias da doença no Brasil, verificou-se que a taxa de detecção das regiões Sul, Norte e Centro Oeste foram superiores à taxa nacional, estabelecendo assim um foco maior por parte da saúde pública, devido ao seu principal meio de transmissão, além de favorecer a infecção por HDV (BRASIL, 2017).

O HBV pertence à família Hepadnaviridae e a sua partícula viral infecciosa é formada por nucleocapsídeo proteico e envolta por um envelope lipoproteico originado da última célula contendo três formas do antígeno de superfície do vírus (HBsAg). No interior da partícula, é encontrada a enzima DNA polimerase viral, que completa o genoma do vírus durante as infecções. O HBsAg é uma glicoproteína antigênica presente na superfície do envelope do HBV cuja presença no soro do paciente é indicação de uma infecção ativa. Esse antígeno é utilizado em preparações de vacinas e kits diagnósticos, por sua capacidade de ativar uma resposta imunológica (KARRON; COLLINS, 2007).

Atualmente, não existem indústrias ou empresas nacionais disponíveis para a produção escalonável do HBsAg. Perante isso, os insumos são importados tanto para fins vacinais como para o diagnóstico. Assim, o sistema de expressão do antígeno HBsAg em células de inseto proposto anteriormente por Silva (2016) poderá ajudar no desenvolvimento 
de kits diagnósticos para a Hepatite B no país, e ser um interessante passo para se pensar em uma produção de antígeno vacinal nacional.

Os baculovírus têm sido utilizados amplamente como vetores de expressão de genes heterólogos em células de inseto nos últimos anos. Deste modo, inúmeras proteínas de importância médica e econômica foram expressas em níveis elevados aplicando esse sistema. A produção do antígeno de superfície HBsAg fusionado à proteína poliedrina do baculovírus é uma estratégia promissora para expressão e purificação destas proteínas em larga escala para a área da saúde humana. O HBsAg tem um papel fundamental no diagnóstico e prevenção da hepatite B. Este antígeno é o marcador sorológico indicativo de infeç̧ão presente pelo HBV, bem como, o único componente da vacina contra o HBV (JARVIS, 1997).

Nesse contexto o presente estudo tem como objetivo analisar estudos que envolvem a expressão de antígenos derivados do HBV em sistema de expressão eucarioto e suas reações cruzadas para a possível construção de kits diagnósticos. 


\section{FUNDAMENTAÇÃO TEÓRICA}

\subsection{0 vírus da Hepatite B e sua partícula viral}

O vírus da hepatite B (HBV) pertecente da família Hepadnaviridae, possui sua partícula infecciosa (vírion), conhecida como partícula Dane (figura 1), formada por DNA envelopado e tem como principal característica a capacidade de infectar as células hepáticas, além de se replicar por transcrição reversa, a partir do RNA pré-genômico, características semelhantes aos retrovírus (HOLLINGER; LIANG 2001). Essa partícula apresenta-se de forma esférica com aproximadamente 42 nanômetros de diâmetro, a qual possui uma estrutura complexa formada for um envoltório externo lipoproteico e interno. 0 envoltório externo é formado por três tipos de glicoproteínas de membrana que se relacionam formando a membrana viral HBs (surface) que constitui o antígeno de superfície do HBV (HBsAg) (figura 1). Internamente ao envelope viral existe o nucleocapsídeo icosaédrico constituído por a proteína HBc (core), que possui aproximadamente 30 a 34 nanômetros de diamêtro, o antígeno do core ( $\mathrm{HbcAg}$ ), o antígeno "e" (HBeAg), o genoma viral e as enzimas DNA polimerase e transcriptase reversa (figura 1) (ZHANG; CAO, 2011).

\subsection{Variabilidade genética}

O genoma do HBV é composto por uma molécula de DNA circular de fita dupla incompleta de, aproximadamente, 3.200 pares de bases (3,2 Kb). O seu genoma viral se encontra organizado em duas cadeias de polaridades invertidas, uma menor e incompleta de polaridade positiva, e outra maior e completa de polaridade negativa, apresentando quatro fases abertas de leitura (ORFs) para a produção das proteínas virais, são elas o capsídeo, o envelope, a DNA polimerase e a proteína regulatória X (figura 2). A tradução do produto da ORF que codifica as proteínas encontradas no envelope pode produzir três formas: Pré-S, Pré-S2 e S. Essas três formas da proteína do envoltório externo do HBV dão origem ao antígeno "s" (surface) do vírus da hepatite B (HBsAg). 
Figura 1: Esquema do HBV (partícula Dane).

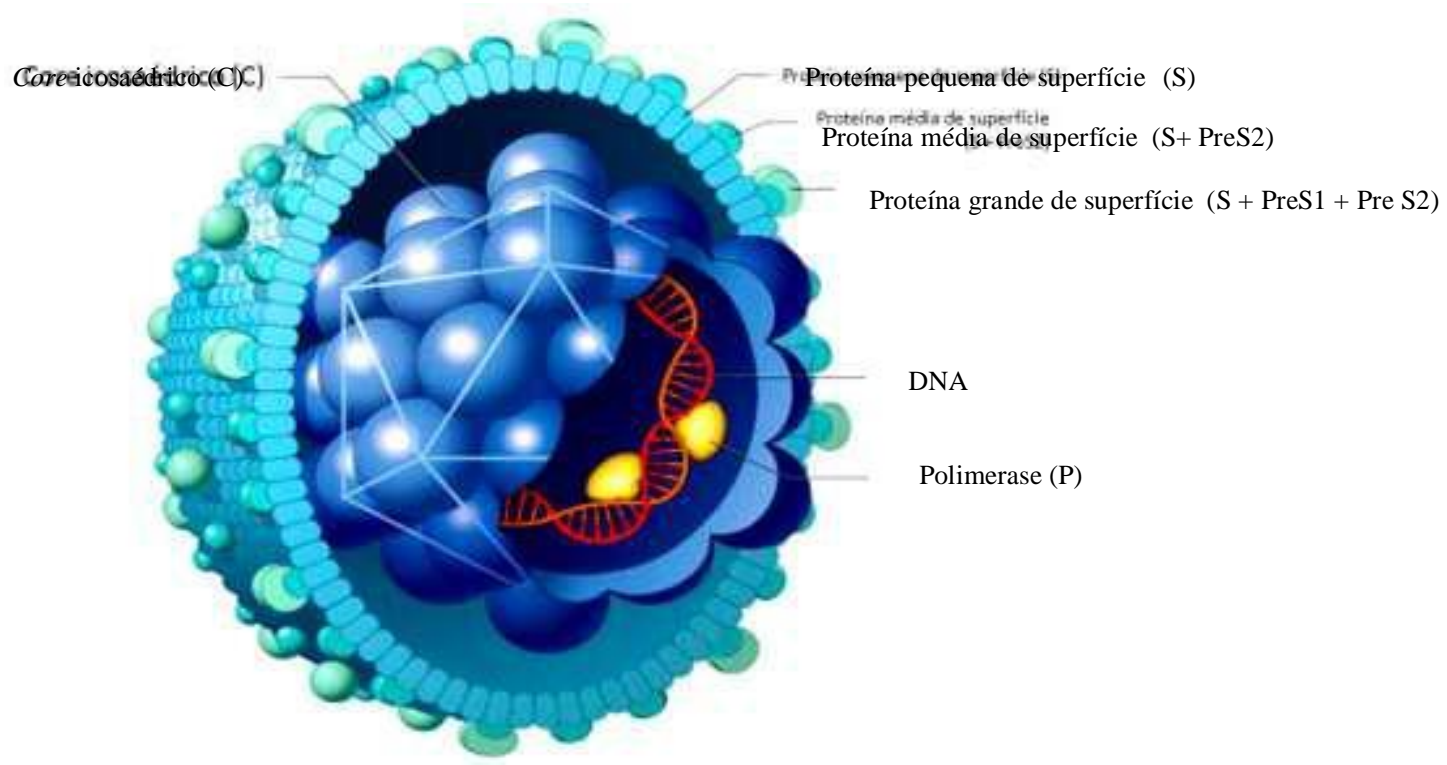

Fonte: Araújo (2011).

A ORF da proteína de capsídeo pode ser traduzida tanto na região Pré-Core (Pré C) quanto na região do capsídeo (ou core), sintetizando as proteínas do HBcAg. Os produtos de Pré $C$ são processados no retículo endoplasmático e um desses produtos de processamento é secretado da célula, originando a porção "e" do vírus (HBeAg) (FIELDS; KNIPE; HOWLEY, 2007; LIANG, 2009). Enquanto a ORF de enzima DNA polimerase (P) é responsável por sua síntese (LEE, 1997), a de proteína regulatória $X$ tem como função a síntese da proteína $X$, que está ligada a replicação viral (GROB, 1998; LIANG, 2009).

Apesar do vírus da hepatite B ser constituído por DNA, a ausência de atividade revisora da DNA polimerase viral the confere uma grande diversidade genética, através do sequenciamento da porção $S$ do genoma, oito genótipos (denominados pelas letras de $A$ até H) foram classificados de acordo com as ocorrências, que possuem distribuições geográficas distintas (MELLO et al., 2007; SABLON; SHAPIRO, 2005; TATEMATSU et al., 2009; TRAN; TRINH; ABE, 2008). 


\subsection{Ciclo de replicação do vírus HBV}

O ciclo replicativo do HBV (figura 3) se inicia após o reconhecimento dos receptores da célula hospedeira, onde o vírus se liga à membrana mediada por proteínas de envelope, em seguida a partícula viral será internalizada por endocitose.

Figura 2: Representação esquemática da organização genômica do HBV.
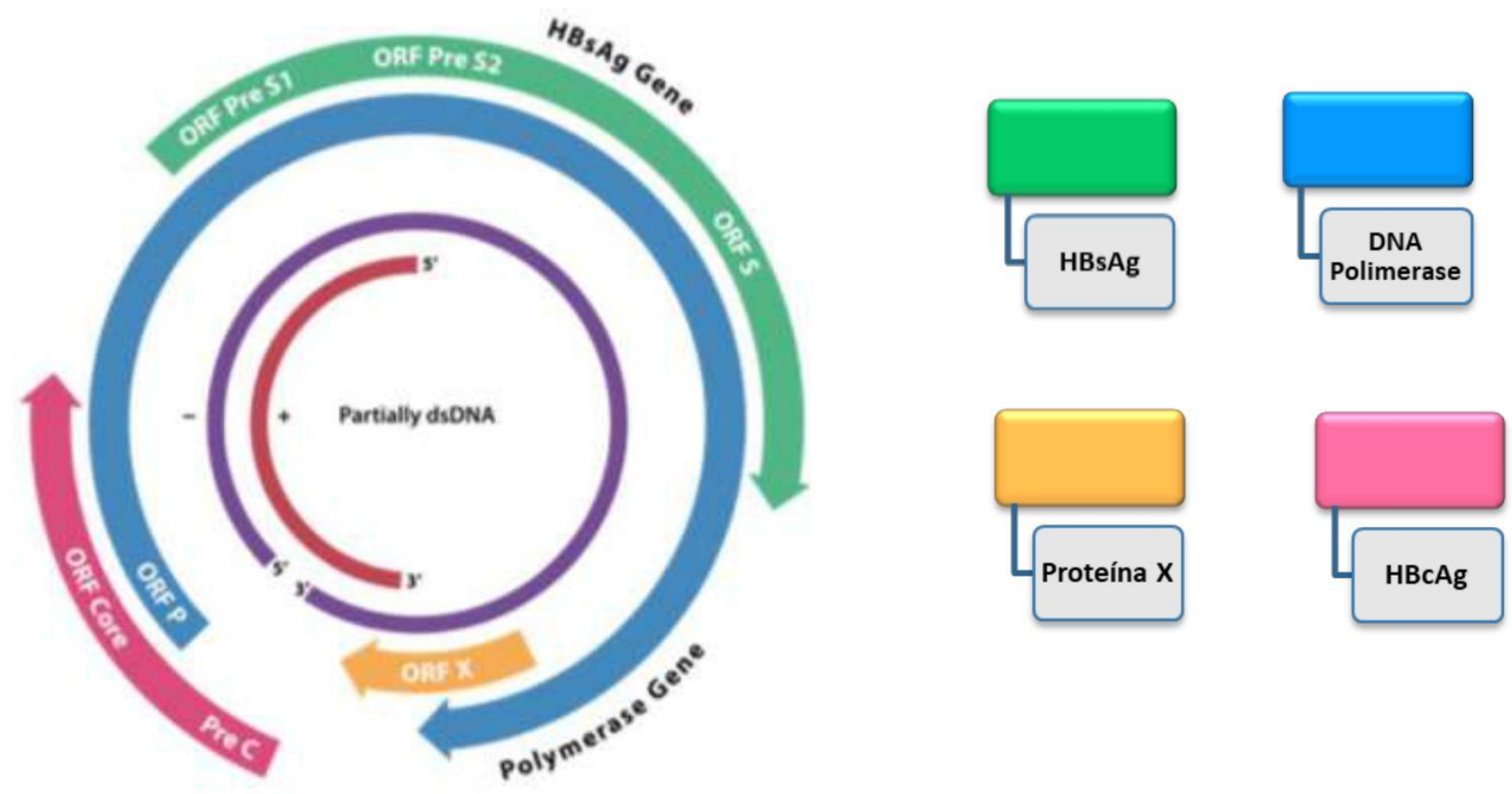

Fonte: Brasil (2015).

Esses receptores de membrana usados pelo vírus, encontrados nos hepatócitos, ainda não estão completamente elucidados. Posteriormente o envoltório externo é fundido a membrana celular, onde é removido liberando o capsídeo no citoplasma que futuramente será transportado para o poro nuclear, ocasionando a liberação do genoma no interior do núcleo celular. Uma vez no núcleo celular, o genoma se liga a fatores de reparo do DNA celular e é maturado na forma de DNA circular covalentemente fechado (cccDNA). Essas moléculas se mantêm de forma epissômica e são usadas pela RNA polimerase II do hospedeiro para transcrever RNAs mensageiros pré-genômicos e sub-genômicos, que quando transportados para citoplasma são traduzidos em proteínas virais. Os RNAs transcritos serão usados para a produção de novas partículas virais, ou são encapsulados nas partículas nascentes junto à 
polimerase viral para serem retrotranscritas, gerando novos genomas virais (FIELDS; KNIPE; HOWLEY, 2007; GERLICH, 2013).

Os novos capsídeos virais podem migrar novamente para o núcleo, liberando novos genomas virais no nucleoplasma, ou podem ser usados para a montagem de novas partículas infecciosas em corpos multivesiculares, que serão liberados no meio extracelular. As partículas subvirais são liberadas pela via trans-Golgi, tais partículas podem ser filamentosas, esféricas, que não são infecciosas, e de Dane (partícula viral completa). Essas partículas subvirais correspondem à maior parte do $\mathrm{HBsAg}$ encontrado na corrente sanguínea de indivíduos portadores da hepatite B (GERLICH, 2013; LEE; AHN, 2011).

\subsection{História da doença associada a infecção pelo vírus HBV e diagnóstico laboratorial}

A hepatite B apresenta forma aguda, porém pode evoluir para a forma crônica nos indivíduos infectados. As hepatites agudas benignas geralmente são confirmadas pelo aumento dos níveis séricos da alanina aminotransferase (ALT) e aspartato aminotrasnferase (AST), indicando lesões no fígado, porém o indivíduo apresenta sintomas inespecíficos, com leves alterações gastrintestinais. Após a fase inicial, o quadro pode evoluir para a forma ictérica da doença, seguida de uma fase de convalescença, período no qual ocorre o desaparecimento da icterícia, ou seja, o indivíduo apresentará melhora progressiva do seu quadro clínico (GONÇALVES JUNIOR, 2013). Normalmente, durante a forma aguda da doença, o DNA viral pode ser detectado com o uso de técnicas moleculares durante o período de um mês a partir da infecção na circulação sanguínea. No entanto, esses níveis serão relativamente baixos por aproximadamente seis semanas (102 a 104 cópias de genoma viral por mililitro). A detecção para o DNA do HBV e dos antígenos virais (HBeAg e HBsAg) estarão no auge após esse período de seis semanas, contudo a presença dos antígenos virais é variável e dependem da fase da doença para serem detectados (ASPINALL et al., 2011).

A primeira resposta humoral do sistema imune, normalmente, ocorre contra o antígeno core do vírus ( $\mathrm{HBCAg}$ ) fazendo com que os anticorpos IgMs surjam precocemente. Posteriormente surgem os anticorpos IgG Anti-HBc, que permanecem na corrente independentemente do curso da infecção. 
Figura 3: Ciclo de replicação do vírus da Hepatite B.

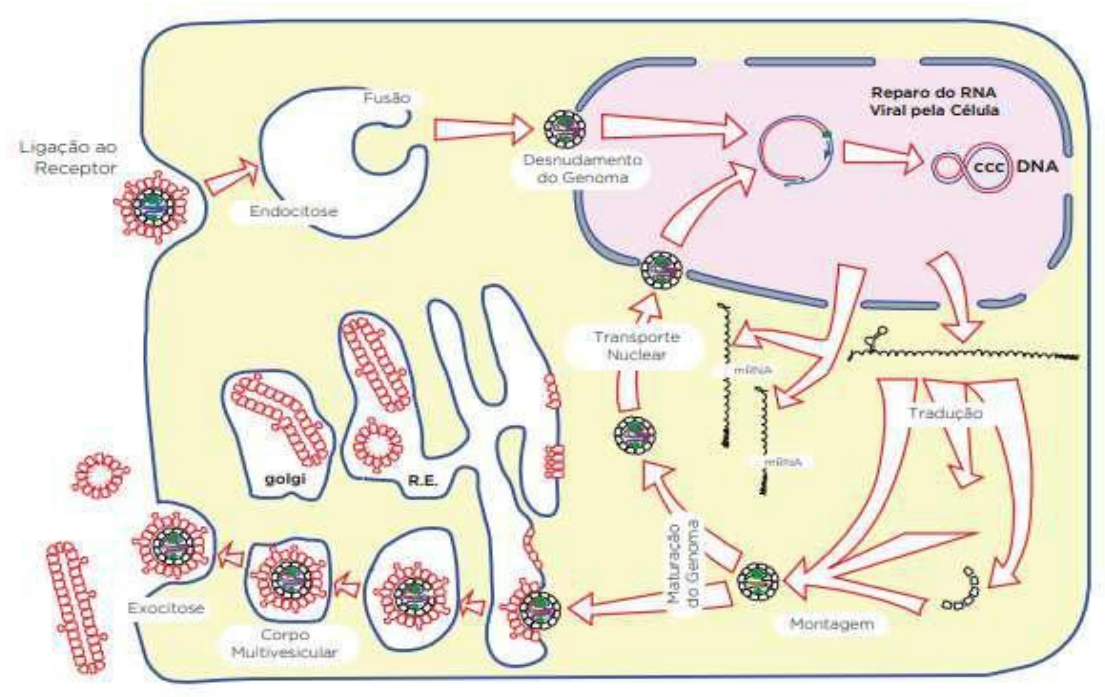

Fonte: Brasil (2015).

Entre a décima e a décima quinta semana após a infecção, os níveis séricos das aminotranferases apresentam aumento (ALT e AST), indicando danos no tecido hepático mediado por resposta a células T. Experimentos em animais realizados em estudos demonstraram que o DNA viral no soro pode se tornar indetectável antes mesmo que ocorra a elevação de ALT (GUIDOTTI et al., 1999). No entanto, as atuais técnicas moleculares são extremamente capazes de detectar uma carga viral baixa (abaixo de 100 cópias/mL) (SILVA et al., 2004). Grande parte dos adultos infectados conseguem reverter a sintomatologia e desenvolver anticorpos específicos contra os antígenos circulantes ( $\mathrm{HBeAg}$ e $\mathrm{HBsAg}$,) garantindo proteção à longo prazo contra a doença. Mesmo com a recuperação do paciente, o DNA viral ainda pode ser encontrado em baixos níveis e imunidade humoral e celular controla sua expressão (FIELDS; KNIPE; HOWLEY, 2007). No caso da ocorrência de mutações nas regiões précore e core, a expressão do HBeAg será alterada, impedindo sua detecção, fazendo com que não ocorra a soro conversão para o anti-HBe (SITNIK; PINHO, 2004).

A Hepatite B na forma crônica é caracterizada pela presença persistente do antígeno HBsAg no soro de um indivíduo infectado por aproximadamente seis meses ou mais (ASPINALL et al., 2011; BRASIL, 2009). Como no curso da infeç̧ão podem ocorrer inserções da parte do genoma do HBV ao genoma do hospedeiro, é possível existir indivíduos com o antígeno HBsAg circulante, mesmo que a replicação viral seja mínima ou praticamente inexistente no tecido hepático. Por essa razão, a definição da infecção crônica baseado na detecção de HBsAg circulante pode gerar amplos estados virológicos e patológicos que devem ser avaliados correlacionando com o estado clínico do paciente (ASPINALL et al., 2011; 
SEEGER; MASON, 2000). Alguns indivíduos infectados com o HBV, não apresentam o antígeno HBsAg detectável, denominado infecção oculta (IOBG). De acordo com estudos, esse tipo de infecção tem a prevalência reduzida na população geral, porém é mais presente entre pessoas que fazem usuários de drogas injetáveis, imunossuprimidos e paciente que fazem hemodiálise (FERREIRA et al., 2009; MATOS et al., 2013; OCANA et al., 2011; SILVA et al., 2004).

De modo geral, a infecção crônica da hepatite B pode ser dividida em quatro fases (BRASIL, 2011): imunotolerância, onde a replicação viral estará elevada, existindo uma tolerância do sistema imune e sem indicações de lesão hepatocelular (transaminases normais ou próximas do normal). Imunorreação, com a diminuição da tolerância imunológica, ocorre agressão as células hepáticas, onde ocorre a replicação viral, gerando o aumento das transaminases. Portador inativo, os níveis de replicação viral estarão diminuidos ou indetectáveis, transaminases normais e, normalmente, soroconversão para anti-HBe. O escape viral pode ocorrer por incorporação do DNA viral ao genoma das células hospedeiras ou mediante atenuação da atividade imunológica do hospedeiro, seja por meio de mutações virais, seja por tratar-se de pacientes com imunodepressão. Reativação, onde em seguida à fase do portador inativo, pode ocorrer a reativação viral, gerando o retorno da replicação.

A hepatite B é uma doença imunoprevenível, ou seja, existe uma vacina para prevenção. Essa vacina é altamente eficiente e é disponibilizada gratuitamente pelo governo brasileiro no serviço público de saúde, fazendo parte do calendário de vacinação infantil. Para que qualquer indivíduo tenha acesso à vacina é preciso que se enquadre nos critérios estabelecidos pelo Ministério da Saúde (BRASIL, 2015). Outras formas importantes de prevenção da infecção são a adoção do uso de preservativo nas relações sexuais e o não compartilhamento objetos de uso pessoal (BRASIL, 2014).

\subsection{Epidemiologia}

$A$ hepatite $B$ permanece uma problemática para a saúde pública, não apenas para 0 Brasil, mas em todo o mundo, mesmo com a existência de uma vacina eficaz desde 1981. Estima-se que existam 400 milhões de carreadores do vírus da hepatite $B$ mundialmente e que de 15 a 40\% desses chegam ao óbito anualmente por doenças hepáticas relacionadas à ação do VHB (FIGUEIREDO et al., 2016).

Segundo Boletim Epidemiológico do Ministério da Saúde (MS), 212.031 casos de 
hepatite B foram notificados entre os anos de 1999 a 2016. Desses, a maioria são encontrados na região Sudeste $(35,4 \%)$, seguida das regiões Sul $(31,6 \%)$, Norte $(14,2 \%)$, Nordeste $(9,4 \%)$ e Centro-Oeste (9,3\%) (Gráfico 1). Em razão do sexo, é possível verificar que apesar da exposição ao VHB ser significativamente mais precoce nas mulheres, o período máximo de exposição do sexo masculino é relativamente maior, possivelmente devido às diferenças em padrões de comportamento sexual, resultando em menores taxas de mulheres infectadas. Conforme o Departamento de Informática do Sistema do Único de Saúde (DATASUS), em 2010, mil trezentos e cinquenta casos de hepatite B foram registrados na região Centro-Oeste, sendo que desses, 15,63\% incidiam no entorno de Brasília (BRASIL, 2017; FIGUEIREDO et al, 2016).

Gráfico 1: Proporção de casos de hepatites virais notificados segundo regiões. Brasil, 1999 a 2016.

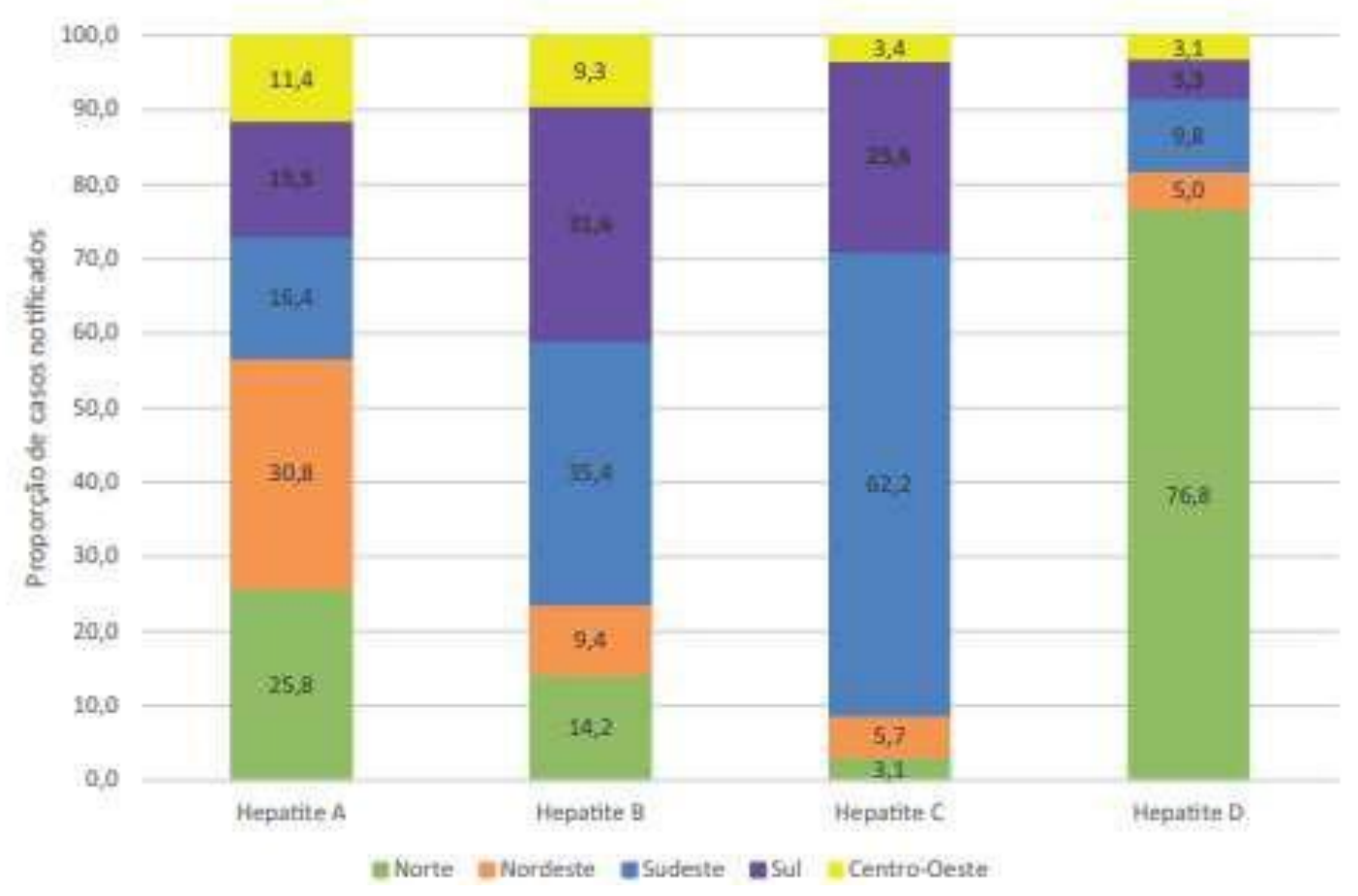

Fonte: Brasil (2017).

Em 1992, a Organização Mundial da Saúde (OMS) recomendou que todos os países implementassem a vacina contra hepatite $B$ nos programas pediátricos de rotina, visando reduzir as taxas de infecção aguda, transferências congênita e perinatal da hepatite $B$, e a manifestação crônica da doença, frequentemente não sintomático na criança, mas que possibilitam sequelas graves na vida adulta e faz cíclica a transmissibilidade (CDC, 2011).

As taxas dos modos de transmissão variam conforme a prevalência do vírus. Em áreas 
com alta prevalência ou endêmicas, onde vivem aproximadamente $45 \%$ da população global, a infecção perinatal ou vertical se sobressai, sendo responsável por cerca de $8 \%$ dos casos de infecção crônica. Em áreas de prevalência intermediária, correspondente a 43\%, predomina-se, a transmissão horizontal, através de exposições percutâneas. Relações sexuais desprotegidas e a utilização de drogas por via intravenosa em adultos são as principais vias de disseminação nas áreas de baixa prevalência onde vivem $12 \%$ da população mundial. A transmissão perinatal também pode ser vista nos países não endêmicos, sobretudo nas crianças nascidas de mães infectadas e que não recebem ou não realizam a imunoprofilaxia adequadamente (FIGUEIREDO et al, 2016).

O Brasil de maneira geral é classificado como um país de baixa-intermediária prevalência de infecção por hepatite $B$, entretanto, a região Norte, principalmente estados da Amazônia (Amazonas, Acre, Rondônia e Roraima) detém prevalência alta (Gráfico 2) (FIGUEIREDO et al, 2016).

Gráfico 2: Taxa de incidência de casos de hepatite B segundo UF e capital de residência. Brasil, 2016.

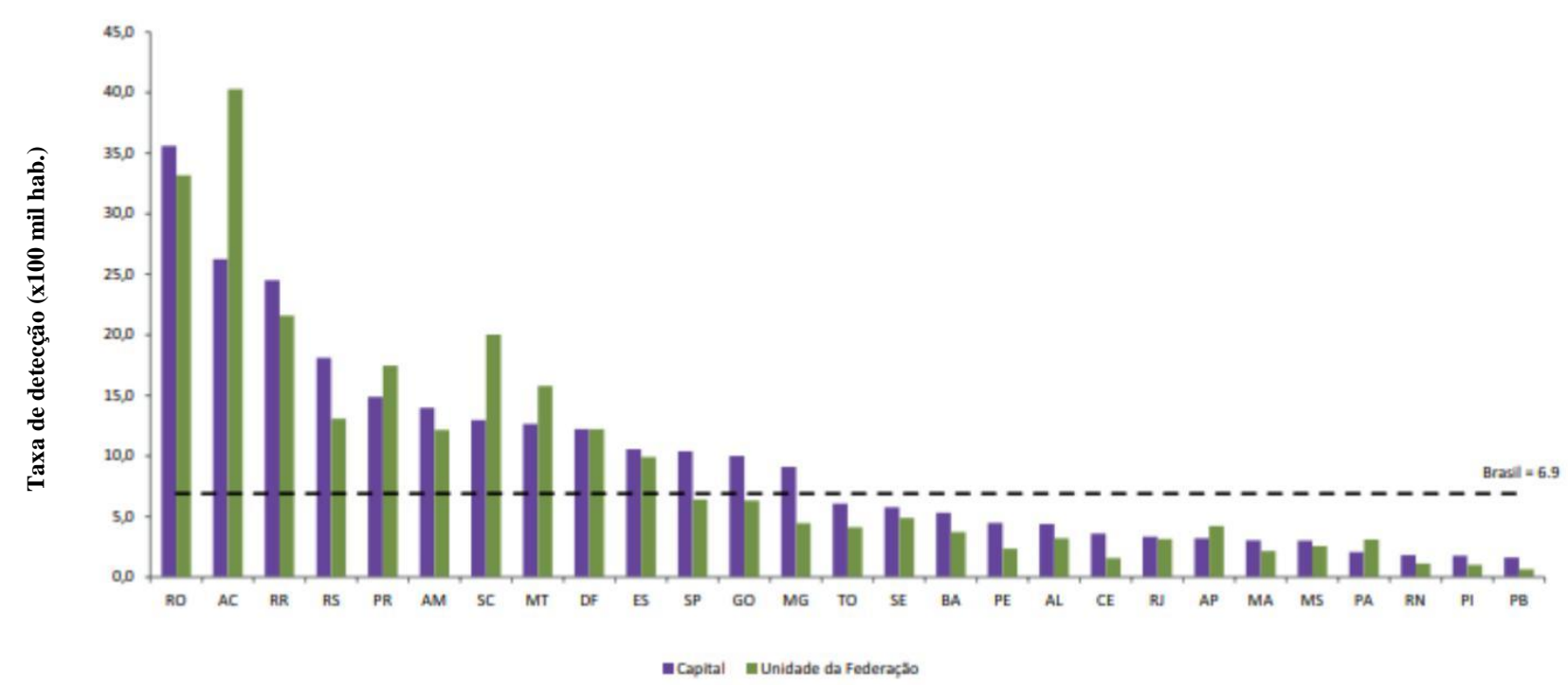

Fonte: Brasil (2017). 


\subsection{Resposta imunológica}

A infecção pelo HBV pode ser curada espontaneamente antes do desenvolvimento de uma resposta imune humoral, enquanto a resposta imune inata na resolução da infeção não está totalmente elucidada. No entanto, é importante não pode ser descartada, devido observações laboratoriais em que o HBV desapareceu tanto da circulação, quanto do fígado antes mesmo que se tenha detectado qualquer resposta imune adaptativa (GUIDOTTI et al., 1999). Em estudos laboratoriais os efeitos antivirais dos interferons de tipo I (IFN- $\alpha$ e IFN- $\beta$ ) foram capazes de incitar um mecanismo de inibição na formação de novos capsídeos do HBV, bem como de deteriorar os capsídeos existentes e degradar o RNA do HBV sintetizado (MCCLARY et al., 2000). Essa inibição pode também ser mediada pela ação do interferon de tipo II (IFN- $\gamma$ ), que é produzido por células NK e por células T ativadas (BARON et al., 2002; KAKIMI et al., 2001).

Pacientes com a capacidade de recuperar-se espontaneamente da infecção, normalmente, apresentam uma resposta imunológica acentuada e multi-epítopo $G$, mediada por células T CD4+ e CD8+ detectáveis na circulação, onde a resposta de CD8+ é determinante na recuperação do paciente (KAKIMI et al., 2001; THIMME et al., 2003).

Anticorpos específicos contra o HBV, além de pesquisa por antígenos e ácidos nucleicos virais, são importantes indicadores para a detecção de estágios específicos da doença (figura 4). A IgM anti-HBc é um marcador da infecção de fase incial, enquanto que anticorpos específicos para o $\mathrm{HBeAg}$ e para o $\mathrm{HBsAg}$ indicam uma resposta favorável para a infecção (FUNG et al., 2014; MARUYAMA et al., 1993). Os anticorpos anti-HBs são neutralizantes e mediadores da imunidade preventiva, induzidos pela vacinação. Os anticorpos anti-HBc e anti-HBs permanecem por longos períodos no indivíduo, sendo que o anticorpo anti-HBs confere proteção contra o vírus (MARUYAMA et al., 1993).

Mesmo com a ação protetora da imunidade adquirida por meio da infecção, traços do vírus HBV podem ser encontrados na corrente sanguínea de alguns indivíduos, indicando a manutenção da replicação viral. A presença do vírus no sangue seria controlada tanto pela resposta imune celular, quanto humoral. Um fato que comprova essa hipótese é a análise da reativação do HBV em alguns indivíduos imunodeprimidos em razão ao uso de quimioterapia (KAWATANI et al., 2001; LAU, 2002). Durante o curso da infecção, podem ser escolhidos variantes do vírus da hepatite $B$ que apresentam mutações nos epítopos imunogênicos virais. Independentemente de estarem relacionadas ao escape da imunidade induzida por 
vacinação, essas variantes do HBV se mantêm em baixas titulações, não afetando, necessariamente, a recuperação do paciente. Mesmo na hepatite $B$ em fase crônica, tais variantes não são comuns, sendo encontrado apenas em indivíduos que apresentam respostas imunes vigorosas, o que pode executar uma intensa pressão seletiva sobre essas populações virais, proporcionando a sua emergência (GUIDOTTI et al., 1996; REHERMANN et al., 1995).

Figura 4: Evolução dos marcadores do HBV nas infecções agudas e crônicas.

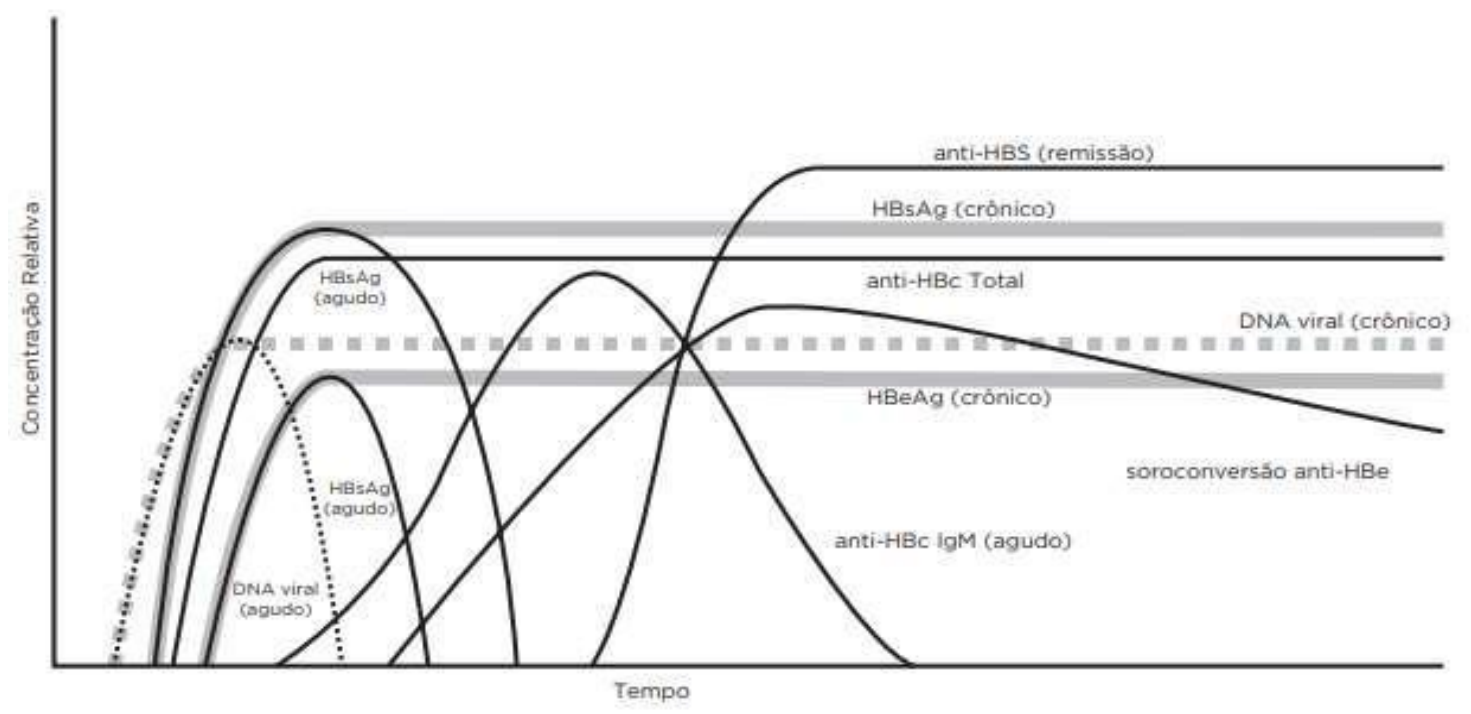

Fonte: Brasil (2015).

\subsection{Diagnóstico imunológico e molecular}

Em casos de suspeita da infecção são os marcadores sorológicos $\mathrm{HBsAg}$, anti-HBc total e anti-HBs que irão estabelecer o diagnóstico da doença (Tabela 1). Esses marcadores circulantes da hepatite podem ser encontrados no soro, plasma ou sangue total de pacientes infectados por meio de imunoensaios (ELISA - Enzyme Linked Immuno Sorbent Assay), possuindo 99\% de especificidade e $98 \%$ de sensibilidade. Além disso, existem os testes rápidos (TR), que são utilizados como metodologia de triagem, portanto possuem alta sensibilidade, porém baixa especificidade e alto custo financeiro. Os TRs tem como princípio a tecnologia de imunocromatografia de fluxo lateral (figura 5), que consiste em uma matriz constituída geralmente por uma membrana de nitrocelulose coberta por acetato transparente facilitando a visualização do teste e o antígeno ou anticorpo é fixado na membrana na forma de linhas, e o resto da membrana é bloqueado com uma proteína inerte, 
assim como nos testes imunoenzimáticos. Atualmente o MS disponibiliza o teste VIKIA HBsAg da empresa BioMérieux Brasil S/A, onde o antígeno HBsAg também pode ser detectado no soro, plasma ou sangue total. O VIKIA é um teste qualitativo baseado na junção de anticorpos monoclonais e policlonais específicos do $\mathrm{HBsAg}$, onde o suporte é composto por um conjugado constituído por uma mistura de anticorpos monoclonais antiHBs ligada a microsferas de poliestireno de cor vermelha e um complexo BSA-biotiniado (conjugado composto de albumina de soro bovino ligado a biotina) ligado a microsferas de poliestireno de cor azul, após introduzir a amostra no poço, essa migra por capilaridade ao longo da membrana. Se o paciente possuir o antígeno, se formará um complexo antígenoanticorpo com os anticorpos específicos do vírus, presentes nas microsferas de poliestireno de cor vermelha. Os complexos antígeno-anticorpos se deslocam ao longo da membrana e fixam-se aos anticorpos anti-HBs formando complexos visíveis na linha vermelha (zona "T"). Como controle, uma linha de cor azul sempre aparece, caso o teste tenha sido realizado corretamente. O complexo BSA-biotinilado ligado a microsferas de poliestireno de cor azul se movimentam ao longo da membrana, ao mesmo tempo em que a amostra, fixando-se ao anticorpo anti-biotina, formando um complexo visível na linha azul (zona "C"). A ausência desta linha invalida o teste.

O HBsAg pode formar imunocomplexos com os anticorpos produzidos (anti-HBs), em consequência ele pode desaparecer do soro de aproximadamente $50 \%$ dos pacientes sintomáticos, deste modo, durante essa fase o anti-HBc é principal indicador para a hepatite B. Os imunoensaios e os TR conseguem detectar o $\mathrm{HBsAg}$, enquanto o anti-HBc só pode ser detectado por imunoensaio, em raras exceções, ambos os marcadores são detectados em todas as fases da infecção, devido a conformação dos TRs e de sua janela imunológica. No curso da doença, o HBsAg é produzido em grandes quantidades e pode ser detectado na maioria dos indivíduos infectados na fase inicial, aproximadamente 30 dias após a infecção. A fase crônica da infecção é definida pela insistência do vírus, ou seja, pela permanência do HBsAg por mais de seis meses, detectada por testes laboratoriais ou TR. O anti-HBc total indica contato prévio com o vírus, por essa razão, o resultado reagente desse marcador só pode ser interpretado após a realização dos outros marcadores que indicam a presença do vírus. Além disso, a janela imunológica para os anticorpos contra o core viral é cerca de 45 dias após o aparecimento do HBsAg. Os testes moleculares também vêm oferecendo uma alternativa para a deteç̧ão mais precoce da infecção pelo HBV (REHERMANN et al., 2005). 
Os testes moleculares também servem para a confirmação de casos de hepatite $B$ em que o HBsAg não é encontrado, como, por exemplo, em casos de infecção oculta. O DNA viral pode ser detectado por meio de PCR em tempo real, podendo ser realizado de forma quantitativa ou qualitativa. Na forma quantitativa, a tecnologia de PCR em tempo real oferece alta sensibilidade analítica $(12 \mathrm{Ul} / \mathrm{mL})$, larga faixa de linearidade, baixo de risco de contaminação, amplificação inespecífica, além de alta velocidade de processamento e boa reprodutibilidade. Enquanto na qualitativa, é utilizando uma metodologia própria, in house, sendo capaz de detectar um limite médio de $100 \mathrm{IU} / \mathrm{mL}$ de DNA-HBV. (CALIENDO et al., 2011; ISMAIL et al., 2011).

Figura 5: Princípio metodológico do teste VIKIA HBsAg.

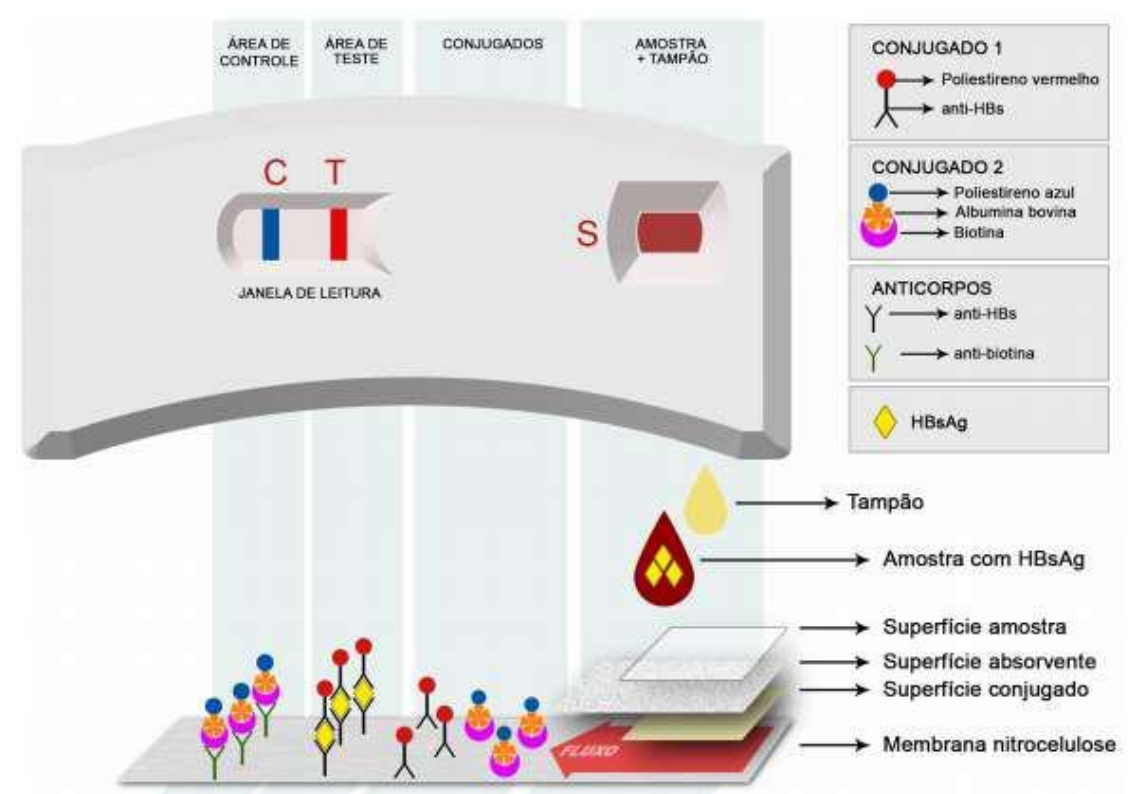

Fonte: Brasil (2017).

\subsection{Sistema de expressão em baculovírus utilizando células de inseto para expressão do HBSAg}

Dentre as ferramentas biotecnológicas disponíveis, o baculovírus, responsável por infectar insetos e atuar no controle de praga (MOSCARDI, 1999; RIBEIRO et al., 1998). São vírus que pertencem à família Baculoviridae, caracterizado por possuir um genoma circular de DNA fita dupla, podendo apresentar cerca de 80 a 200 mil pares de bases como material genético. Além disso, apresenta um capsídeo protéico em forma de bastonete, constituindo 
assim a unidade infectiva do vírus, denominado nucleocapsídeo (ARIF, 1986; O'REILLY et al., 1992; GARCIA-MARUNIAK et al., 2004). Uma característica importante e que diferencia o baculovírus, é a sua capacidade em produzir dois tipos de vírus fenotipicamente diferentes durante o ciclo de infecção, os vírus extracelulares (infecção sistêmica) e os vírus ocluídos (poliedros) (MURPHY et al., 1995).

Tabela 1: Interpretação dos resultados sorológicos.

\begin{tabular}{lll}
\hline Testes Sorológicos & Resultados & \multicolumn{1}{c}{ Interpretação } \\
\hline HBsAg & Não reagente & Ausência de contato prévio com o HBV. \\
Anti HBc total & Sũo reagente \\
Não reagente & \\
Anti HBs & Não reagente a infecção pelo HBV. \\
RBsAg & $\begin{array}{l}\text { Reagente } \\
\text { Reagente }\end{array}$ & Imune após infecção pelo HBV. \\
Anti HBc total & Não reagente & \\
Anti HBs & Não reagente & Imune após vacinação contra o HBV. \\
RBsAg & Reagente & \\
Anti HBc total & Reagente & \\
Anti HBs & Reagente & Infecção pelo HBV. \\
HBsAg & Não reagente & \\
Anti HBc total & & \\
Anti HBs & &
\end{tabular}

Fonte: Brasil - Adaptado (2015)

Além de serem eficientes como bioinseticidas, os baculovírus são também utilizados como sistema de expressão, ou seja, podem expressar genes heterólogos com eficácia. 0 sistema baseia-se na introdução de genes exógenos no genoma do baculovírus de interesse (O’ REILLY et al., 1992, JARVIS, 1997).

Proteínas de importância em diversas áreas, como por exemplo, na medicina e na agricultura, foram expressas em grande quantidade, em cultura de células de insetos usando os baculovírus como vetores de expressão (RIBEIRO et al., 1998). Comparado com outros sistemas de expressão, as vantagens para utilização desses vetores são, a expressão de proteínas heterólogas em concentrações altas, a especificidade dos baculovírus, tornando-o a manipulação mais segura, presença de promotores fortemente ativos durante a fase tardia da infecção sem interferência no ciclo viral, capacidade para clonar grande inserções; co-expressão de dois ou mais genes, ambiente eucariótico para expressão de proteínas 
complexas de eucariotos e simplicidade na utilização (O' REILLY et al., 1992, JARVIS, 1997; RIBEIRO et al., 1998).

A proteína poliedrina é a principal proteína dos poliedros, sendo assim, introduzir uma proteína heteróloga ao corpo de oclusão $(\mathrm{OB})$ dos baculovírus é uma alternativa para produção e purificação em larga escala de proteínas recombinantes. A expressão de proteínas fusionada à poliedrina já foi estudada anteriormente (JE et al., 2003) e se caracteriza pela construção de genes quiméricos entre o gene da poliedrina e o gene heterólogo de interesse. A purificação dos poliedros por centrifugação em gradiente de sacarose é uma metodologia estabelecida e de fácil execução (O’ REILLY et al., 1992). Desta forma, a purificação de proteínas recombinantes fusionadas à poliedrina incorporadas ao OB, facilita a purificação do polipeptídeo de interesse, tornando-se uma solução alternativa para resolver um dos principais problemas na produção de insumos bioecnológicos por engenharia genética. (CHANG et al., 2003).

\subsubsection{Produção de kits diagnósticos}

Os baculovírus têm sido utilizados amplamente como ferramenta de expressão de genes heterólogos em células de inseto e medicina nos últimos anos. Em vista disso, inumeráveis proteínas de importância médica e econômica foram expressas utilizando esse sistema (MILLER, 1997; VAN OERS; PIJLMAN; VLAK, 2015). O antígeno de superfície HBsAg, marcador sorológico indicador de infecção pelo vírus HBV e componente principal de vacinas contra a hepatite $B$, é fundamental para o diagnóstico e prevenção da hepatite $B$ (BRASIL, 2015).

Quando fusionado à poliedrina, o HBsAg pode ser produzido em larga escala, desse modo essa fusão se torna uma estratégia promissora para a saúde publica, uma vez que atualmente não se encontra empresas ou indústrias brasileiras que produzam o HBsAg em grandes quantidades, por isso os insumos utilizados para a produção de kits diagnósticos e vacinas de prevenção são importados. Diante disso, estudos utilizando a expressão da porção small do HBsAg em células de insetos podem futuramente ajudar no desenvolvimento de kits diagnósticos para a Hepatite B e um possível passo para a produção de vacinas totalmente nacional e mais acessível (ARAUJO, 2011).

Araújo (2011), trabalhando com o HBV, obteve sucesso na construção de um baculovírus recombinante, onde expressa a porção small do HBsAg fusionada a região 5' do 
gene da poliedrina do baculovírus AcMNPV (AcPH), porém não conquistou o sucesso na fusão à região 3' do gene. Observando a expressão da proteína recombinante em células de inseto infectadas, acabou revelando que a proteína recombinante sHBsAgAcPH foi produzida tanto in vitro (células de inseto em cultura) como in vivo (larvas de Spodoptera frugiperda). Esse estudo utilizando extratos de células de inseto com o vírus recombinante contendo a proteína sHBsAgAcPH e corpos de oclusão purificados em gradiente de sacarose com base no uso de cadáveres de insetos, foi capaz de ser reconhecido em kits de diagnósticos no Laboratório Central de Saúde Pública do Distrito Federal (LACEN-DF). No entanto, esses corpos de oclusão não possuíam uma forma estabelecida e não foi possível realizar a purificação livre de contaminantes. Diante disso, novas estratégias devem ser pensadas e estudadas para que a produção e purificação possam ser melhoradas, levando em conta que os poliedros recombinantes contendo a proteína de interesse são produzidos e isolados facilmente, uma nova abordagem poderá ser uma excelente alternativa para vacinação e uso em diagnóstico de vertebrados.

Quando comparada a outros sistemas de expressão, como a bacteriana e a de levedura, as células de inseto representam um sistema mais barato e eficiente, devido ao alto nível de expressão dos genes heterólogos. A principal vantagem do sistema utilizando o baculovírus é que elas possibilitam modificações pós-traducionais mais próximas às que acontecem em células de mamíferos, tornando-as adequadas para a produção de vacinas, potentes vetores de terapia gênica, segurança inerente no processo de produção e construção de kits diagnósticos específicos, sensíveis e mais baratos. A maioria dos sistemas de expressão em células de inseto usando baculovírus, disponíveis comercialmente, fundamenta-se na espécie tipo, AcMNPV. Os genes envolvidos no processo de formação de corpos de oclusão e transcritos em fases tardias da infecção têm uma atividade transcricional extremamente elevada nesse período (BARROS, 2007; SILVA, 2016.).

Smith et al. (1983) relatou em seu primeiro trabalho uso de baculovírus como vetor para expressão de proteínas heterólogas, denominando Baculovirus expression vector system (BEVS), utilizando a expressão da proteína beta-interferon em baculovírus geneticamente modificados e para isso foi aplicado o promotor da polh do AcMNPV, comandando a expressão.

Atualmente, a aplicação de BEVS vem sendo estudada e aprimorada, como a construção de linhagens de células de inseto transgênicas capazes de alterar proteínas com 
variações pós-traducionais de células de mamíferos, como por exemplo, a glicosilação com resíduos de ácido siálico. Os baculovírus também são utilizados como vetores de entrega gênica em células de mamíferos, além de apresentar antígenos. Esse sistema resultou na produção de vacinas contra doenças virais baseadas em virus-like particles (VLP), como a Cervarix ${ }^{\circledR}$, conta o Papilomavirus humano (BARROS, 2007; SILVA, 2016.).

O método atualmente mais utilizado para a construção de baculovírus recombinantes

é o sistema comercial Bac-to-Bac (Invitrogen) (figura 6). A estratégia baseia-se na transposição onde o gene de interesse será clonado em um plasmídeo, que possui regiões flanqueadoras de transposição (SILVA, 2016). Esse plasmídeo recombinante se transformará em células de uma bactéria, a E.coli, que apresentará o seu genoma e o do baculovírus formando um grande plasmídeo (bacmídeo), além do gene transposase, responsável por fazer a transposição do gene de interesse para o genoma do baculovírus. Após a transposição,

é feita uma seleção junto a antibióticos. Um mini-prep será realizado para a obtenção do DNA do bacmídeo, onde após essa rápida purificação do será feito a transfecção de células de inseto, onde o DNA do baculovírus por si só infectará essas células. O sobrenadente dessa transfecção conterá o vírus, que poderá ser coletado para a realização da amplificação vrial ou para a determinação do título viral (BARROS, 2007).

\subsection{Tratamento}

O tratamento para HBV tem como objetivo precaver o desenvolvimento da cirrose hepática e/ou carcinoma Hepatocelular (CHC), através da antecipação da soroconversão do HBeAg em anti-HBe. Nessa situação, o tratamento se baseia em dois tipos de agentes terapêuticos, o Interferon e os análogos de nucleotídeos (AN). Os interferons envolvem o interferon convencional, que devido suas altas dosagens diárias, acaba dificultando o emprego no tratamento da HBV, e o interferon peguilado. Os AN envolvem os lamivudina (LVD), o adefovir (ADV) e o entecavir (ETV), que inibem a replicação viral, porém o seu uso prolongado pode selecionar cepas resistentes (BRASIL, 2015).

Nas últimas décadas, vários avanços ocorreram quando se fala em prevenção das hepatites virais. A vacina contra o vírus HBV, atualmente é a forma mais eficaz para a prevenção da hepatite B (CARVALHO; ARAÍJO, 2008).

A primeira vacina existente para prevenir uma hepatite viral foi contra o HBV, foi desenvolvida no início dos anos oitentas e feita a partir do plasma humano. Posteriormente, 
foi substituída por vacinas produzidas mediante a técnica de DNA recombinante.

O HBsAg recombinante, produzido em fungos, atualmente é o antígeno utilizado nas vacinas disponíveis (FERREIRA; SILVEIRA, 2004).

Figura 6: Geração de baculovírus recombinante e gene de expressão.

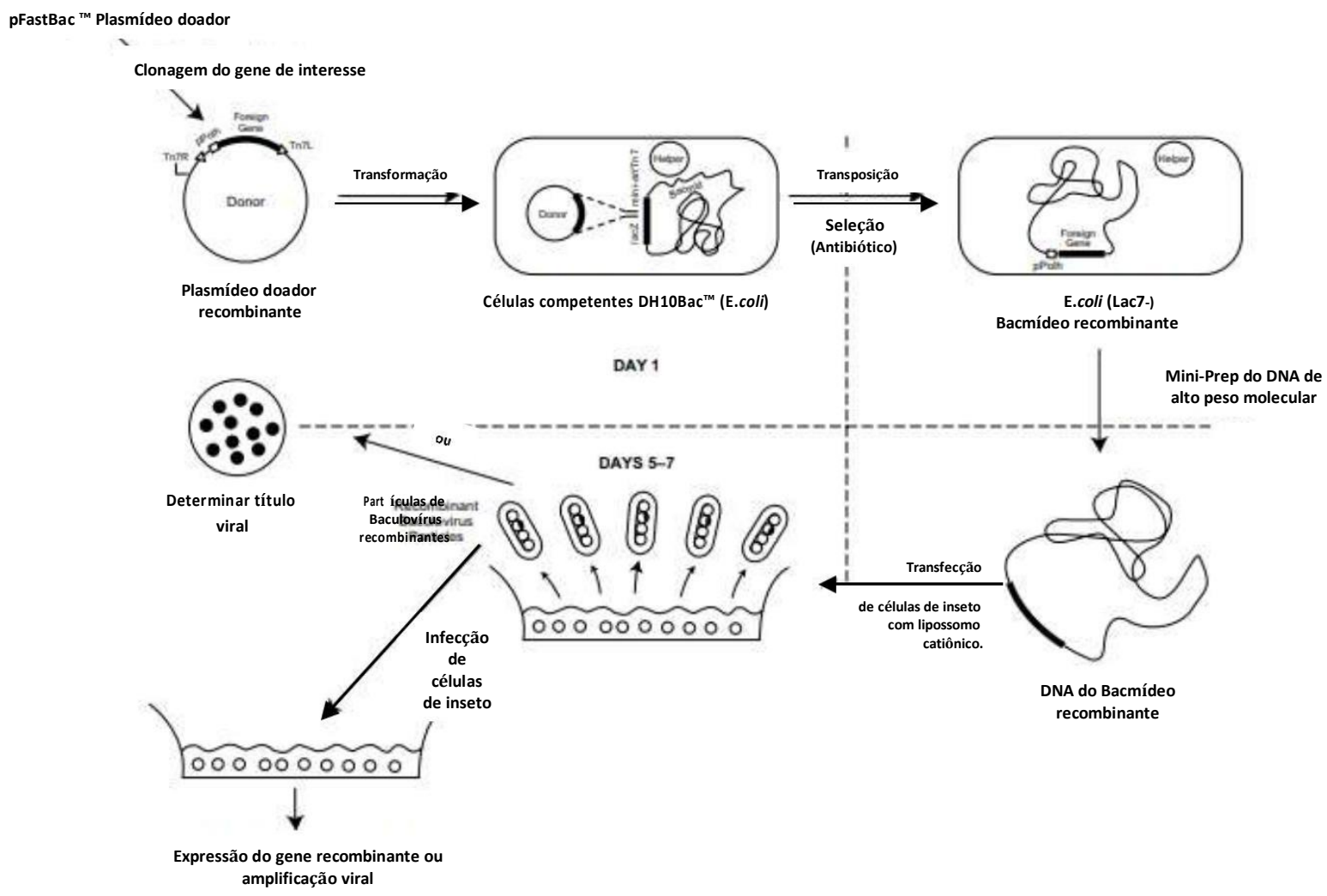

Fonte: Bac-to-Bac (2008). 


\section{METODOLOGIA}

O presente trabalho está sendo desenvolvido em colaboração com Universidade de Brasília (UnB), no laboratório de Virologia e Biologia Molecular do Instituo de Biologia - IB, sob orientação do Profo Titular Dr Bergmann Morais Ribeiro, Profa Dra Anabele de Azevedo Lima e colaboradores. Os resultados apresentados no trabalho são de exclusividade dos parceiros citados.

\subsection{Quantificação das proteínas}

A quantificação das proteínas foi realizado através do kit Quant-iT ${ }^{\mathrm{TM}}$ dsDNA HighSensitivity Assay, esse kit faz dosagem de proteínas através da fluorescência, foram utilizadas as proteínas nas concentrações de 1:100, 1:1000, pura e controle negativo, as proteínas foram diluídas com PBS $1 x$ e adicionado 200 uL de cada amostra a ser testada e 10 uL de reagente Quant-iT em determinados poço da microplaca de 96 poços. Após esse processo foi realizada a leitura a $450 \mathrm{~nm}$.

Tabela 2. Florescência registrada pelo programa SoftMax Pro 6.2.1.

\begin{tabular}{|c|c|c|}
\hline & 1 & 2 \\
\hline$A$ & 39.690 & 37.171 \\
\hline$B$ & 84.458 & 42.855 \\
\hline C & 92.719 & 68.846 \\
\hline D & 5.245 & 4.527 \\
\hline
\end{tabular}

Fonte: Costa, $\mathrm{N}$.

\subsection{Imunoensaio}

Foram realizados testes sorológicos imunoenzimáticos, o ELISA (Enzyme-linked Immunosorbent Assay) indireto, método que se baseia na interação antígeno-anticorpo. As cavidades da placa de ELISA foram cobertas com $50 \mu \mathrm{L}(0,5 \mathrm{ng} / \mathrm{mL})$ antígeno sHBsAg fusionada a poliedrina (proteína recombinante), após ser diluído em PBS 1X (tampão fosfato-salino).

Após quatro horas na câmara úmida, em temperatura ambiente é realizado o descarte e o bloqueio overnight que foi preparado com leite desnatado $(5 \mathrm{~g}$ de leite $+100 \mathrm{~mL}$ de água mille- 
Q) onde foi adicionado 50uL em cada cavidade utilizada. No dia seguinte foi realizada aprimeira lavagem com mistura de PBS $1 X$ e Tween $0,05 \%$, onde foi adicionado $200 \mathrm{uL}$ em cada poço, esse processo foi realizado três vezes.

Após a primeira lavagem, foi acrescentado $2 \mathrm{uL}$ dos soros dos pacientes em cada cavidade e levado para incubação de uma hora $37^{\circ} \mathrm{C}$. Uma hora depois uma nova lavagem foi realizada e em seguida foi colocado 6uL anticorpo secundário IgG (Peroxidase), 644uL de PBS + leite desnatado e levado para uma nova incubação de uma hora à $37^{\circ} \mathrm{C}$.Terminado o tempo de incubação, a última lavagem foi realizada, prosseguindo para a revelação, onde foi utilizado 50uL em cada poço de uma solução preparada com $5 \mathrm{mg}$ de OPD, $13 \mathrm{~mL}$ de tampão citratofosfato $(\mathrm{pH} 4,5)$ e 7 L de peróxido de hidrogênio. Meia hora depois, foi adicionada a solução de parada (HCL 2M) e realizada a leitura à $492 \mathrm{~nm}$.

Em um segundo momento, foram realizados testes sorológicos imunoenzimáticos, 0 ELISA (Enzyme-linked Immunosorbent Assay) indireto, método que se baseia na interação antígeno-anticorpo. As cavidades da placa de ELISA foram cobertas com $50 \mu \mathrm{L}(0,5 \mathrm{ng} / \mathrm{mL})$ antígeno sHBsAg fusionada a poliedrina (proteína recombinante), após ser diluído em PBS $1 \mathrm{X}$ (tampão fosfato-salino). Após overnight na câmara úmida, em temperatura ambiente é realizado o descarte, a primeira lavagem com mistura de PBS $1 \mathrm{X}$ e Tween 0,05\%, onde foi adicionado $200 \mathrm{uL}$ em cada poço, esse processo foi realizado três vezes, após esse processo foi realizado o bloqueio por 2 horas a $37^{\circ} \mathrm{C}$ que foi preparado com BSA (BSA a 2\%) onde foi adicionado 50uL em cada cavidade utilizada

Após o bloqueio, foi realizado a lavagem novamente com PBS 1x e Tween 0,05\%, para realizar a testagem foi necessário fazer processo de inativação viral, tendo em vista, que estávamos manipulando amostras positivas de hepatite $C$, esse tratamento foi realizado com concentração de $0.2 \%$ de Dodecil sulfato de sódio (SDS) e $0.1 \%$ Tween 20 a 60 ㄷ 15 min, após esse tratamento foi acrescentado 50uL dos soros dos pacientes tratados em cada cavidade e levado para incubação de uma hora $37^{\circ} \mathrm{C}$. Uma hora depois uma nova lavagem foi realizada e em seguida foi colocado $2 \mathrm{uL}$ anticorpo secundário IgG (Peroxidase), 2,5 $\mathrm{ml}$ de PBS $1 x$ e levado para uma nova incubação de uma hora à $37^{\circ} \mathrm{C}$. Terminado o tempo de incubação, a última lavagem foi realizada, prosseguindo para a revelação, onde foi utilizado $50 \mathrm{uL}$ em cada poço de uma solução preparada com $5 \mathrm{mg}$ de OPD, $13 \mathrm{~mL}$ de tampão citratofosfato ( $\mathrm{pH} 4,5$ ) e 7uL de peróxido de hidrogênio. Meia hora depois, foi adicionada a solução de parada $(\mathrm{HCL} 2 \mathrm{M})$ e realizada a leitura à $450 \mathrm{~nm}$.

Foram testados 25 amostras de pacientes doados pelo LACEN-DF, as amostras são positivas para hepatite $B$ com presença do antígeno $\mathrm{HBsAg}$, previamente testadas e 
identificados de acordo com a doença pré-estabelecida, porém não tínhamos controle negativo, devido a cobertura vacinal é muito difícil encontrar um soro livre do antígeno HbsAg.

\section{RESULTADOS E DISCUSSÃO}

Os corpos de oclusão produzidos em lagartas Spodoptera frugiperda infectadas com os vírus recombinantes foram testadas contra o Kit Laboratorial anti HBsAg qualitativo e quantitativo da empresa Wama Diagnóstica. Para o teste qualitativo foram avaliadas cinco concentrações diferentes das proteínas totais produzidas neste trabalho (100ng, 200ng, 300ng, 400ng e 500ng), sensibilizadas na cavidade da microplaca de ELISA da marca Costar. Todas as cinco concentrações testadas contra o controle positivo (soro humano positivo para anti-HBsAg) disponível no kit, obtiveram reação positiva. A concentração de 100 ng de proteína total dos OBs recombinantes foi selecionada para determinar o valor mínimo detectátvel em relação a concentração de anticorpo anti-HBsAg em soro $(10,20,40,80$ e $160 \mathrm{mUl} / \mathrm{mL}$ ), disponíveis no Kit Laboratorial Anti HBsAg Quantitativo. Utilizamos como controle positivo, soro contendo anticorpos anti-HBsAg e controle negativo, soro sem anticorpos anti-HBsAg disponível no Kit. Todas as cinco concentrações de anticorpo antiHBsAg em soro testadas reagiram com as proteínas sensibilizadas em microplaca (Figura 4).

A

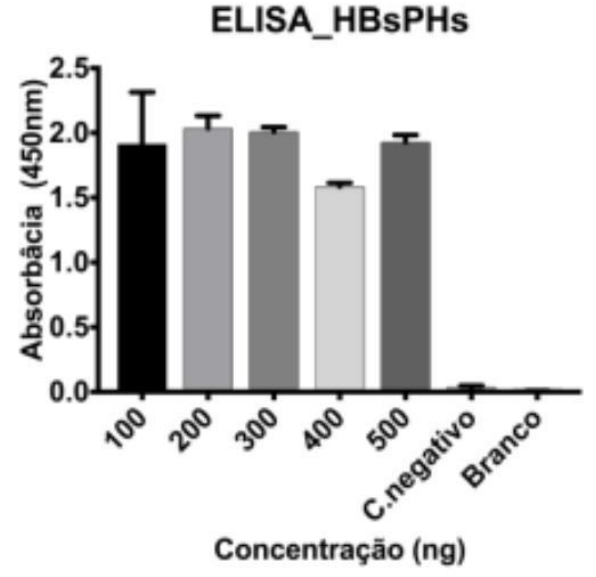

B

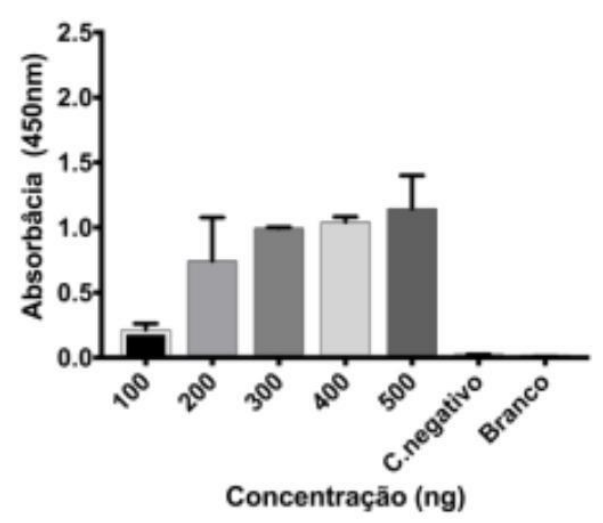


C

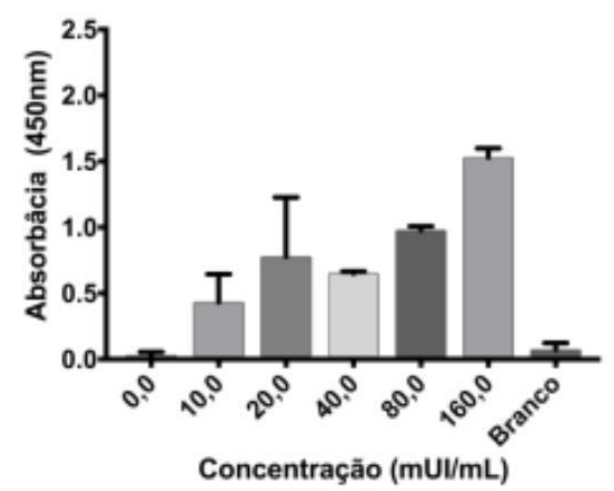

D

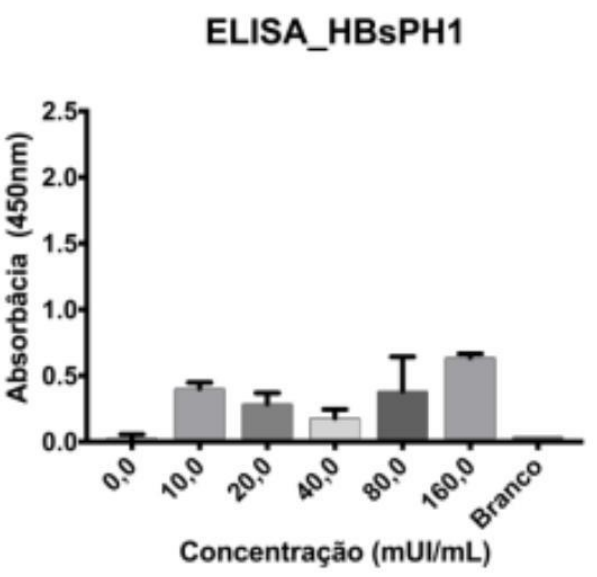

Figura 4. ELISA utilizando Kit Laboratorial Anti HBsAg Qualitativo e Quantitativo da empresa Wama Diagnóstica. Gráfico apresenta o resultado da absorbância (450nm) do imunoensaio contendo os $\mathrm{OBs}$ recombinantes ( $\mathrm{HBsPHs}$ e $\mathrm{HBsPH} 1$ ). ELISA qualitativo ( $\mathrm{A}$ e $B$ ) com diferentes concentrações da proteina recombinante e quantitativo ( $C$ e $D$ ) com diferentes concentrações de anti HBsAg em soro comercial. Soro controle negativo (soro humano negativo para anti-HBsAg presente no Kit) e branco (somente substrato cromógeno) Absorbância lida em leitor óptico (spectramax) a 450nm.

O primeiro teste de ELISA indireto não foi conclusivo, pois apresentou análises de absorbância semelhante e estatística sem significância, inclusive com o controle negativo (Figura 5). Havendo assim, a necessidade de se realizar mais testes de ELISA indireto, com quantidade de soro maior, para identificar possíveis reações cruzadas entre soro de pacientes reagentes com hepatite $B, C, A$ e $C M V$. 

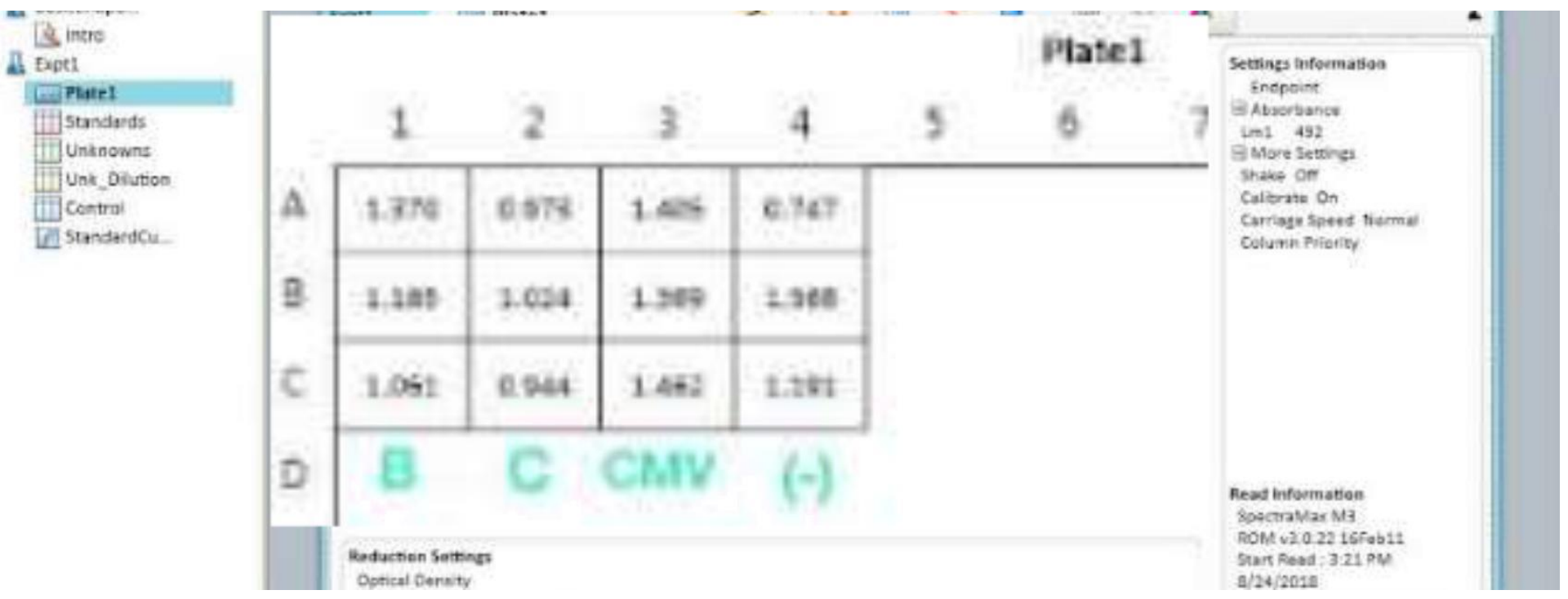

Figura 5: Absorbância registrada pelo programa SoftMax Pro 6.2.1, da reação cruzada entre o antígeno possuindo regiões antigênicas do vírus da hepatite $B$ e soro de pacientes reagentes para hepatite $\mathrm{C}$ e CMV. Como controle negativo utilizou-se soro de paciente não reagente para hepatite $B$.

No segundo ELISA (figura 6) realizado com os soros dos pacientes doados pelo LACEN-DF obtivemos a presença do HBsAg em todos os poços, exceto o branco, porém ainda não temos como comprovar se houve reação cruzada devido os soros serem positivos para outras patologias, como hepatite $C$ e hepatite $A$, os resultados obtidos são satisfatórios tendo em vista a especificidade do teste em relação ao antígeno $\mathrm{HbsAg}$, porém foram testados 25 amostras, sendo necessário realizar novos testes para identificar o intervalo de confiança do teste em questão.

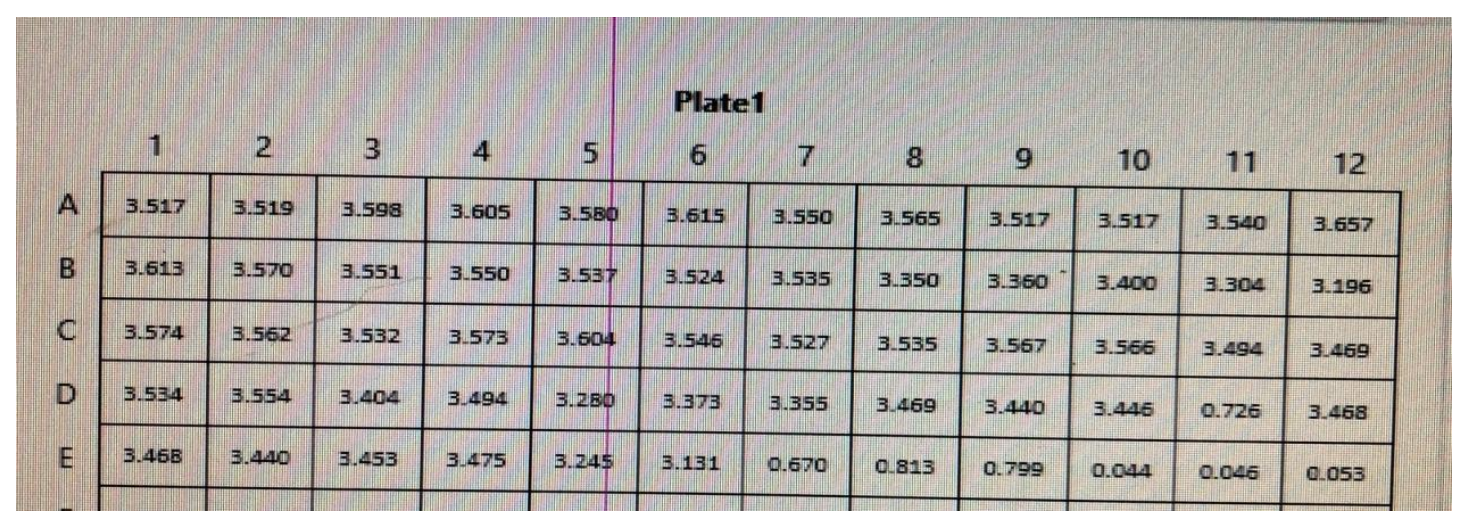

Fonte: Costa, $\mathrm{N}$.

Figura 6: Absorbância registrada pelo programa SoftMax Pro 6.2.1, da reação cruzada entre o antígeno possuindo regiões antigênicas do vírus da hepatite B e soro de pacientes 
reagentes para hepatite $B$, hepatite $C$ e hepatite $A$. Para o branco foi utilizado PBS $1 x$. No caso, as amostras testadas são do A1 a E6, sendo que no D11 e D12 foram desconsiderados esses resultados devido às diferenças entre as duplicatas, e o branco E7 e E8. As absorbâncias foram muito similares entre si, considerando que as amostras testadas eram soros positivos, sendo necessário realizar novos testes ELISA para ter um intervalo de confiança maior.

\section{CONSIDERAÇÕES FINAIS}

Comparado com outros sistemas de expressão, a ferramenta biotecnológica, o baculovírus, tem como principais vantagens, o potencial para expressão de proteínas heterólogas em níveis altos, alta especificidade dos baculovírus, a existência de promotores fortemente ativos na fase tardia da infecção sem pertubação no ciclo do vírus, a possibilidade de clonagem de grandes inserções, co-expressão de dois ou mais genes, simplicidade de manipulação e baixo custo financeiro. Diante disso, a análise de produção de antígeno de superfície HBsAg pelo sistema de expressão em baculovírus e células de inseto é um estudo bastante promissor para a área da saúde, principalmente para a área biomédica. Analisando dados epidemiológicos os números de infeç̧ões pelo vírus HBV está sempre aumentando ao longo dos anos, considerando esses dados a produção de kits diagnósticos e futuramente a elaboração de antígenos vacinais conta a hepatite $B$ totalmente nacionais e mais acessíveis, tanto para o governo quanto para a população, é um estudo de grande relevância para a saúde pública brasileira. 


\section{REFERÊNCIAS}

ARAÚJO, A.C.O. Nova abordagem para expressão da partícula sSHbsAg do antígeno HBsAg do vírus da Hepatite B em células de inseto. 2011. 81 f. Dissertação (mestrado) do programa de pós-graduação em Patologia molecular da Universidade de Brasília, Brasília, 2011.

ARIF, B. M. The structure of the viral genome. In: DOERFLER, W; BOHM, P. The Molecular Biology of Baculoviruses. 131. ed.; Berlim: Springer-Verlag, 1986. p. 21-29,

ASPINALL, E. J. et al. Hepatitis B prevention, diagnosis, treatment and care: [revisão]. Occupational medicine. Occupational Medicine: Oxford, v. 61, p. 531-540, Dez. 2011.

BARON, J. L. et al. Activation of a Nonclassical NKT Cell Subset in a Transgenic Mouse Model of Hepatitis B Virus Infection. Immunity: San Francisco, CA, v. 16, p. 583-594, Abr. 2002.

BARROS, M. C. Expressão de proteínas do vírus da dengue em células de inseto utilizando o sistema baculovírus de expressão. 2007. 108 f. Dissertação (mestrado) do programa de pós-graduação em Patologia molecular da Universidade de Brasília, Brasília, 2007.

BRASIL. A B C D E do Diagnóstico para as Hepatites Virais. Brasília: Ministério da Saúde, 2009.

BRASIL. Diagnóstico de hepatites virais, Brasília: Ministério da saúde, 2014.

BRASIL. Hepatites virais: o Brasil está atento, Brasília: Ministério da saúde, 2008.

BRASIL. Manual técnico para diagnóstico das hepatites virais, Brasília: Ministério da Saúde, 2015.

BRASIL. Protocolo Clínico e Diretrizes Terapêuticas para o Tratamento da Hepatite Viral Crônica B e Coinfecções. Brasília: Ministério da Saúde, 2011.

CALIENDO, A. M. et al. Multilaboratory evaluation of real-time PCR tests for hepatitis $B$ virus DNA quantification. Journal of clinical microbiology: Atlanta, GA, v. 49, p. 2854-2858, Ago. 2011.

CARVALHO, A. M. C.; ARAÚJO, T. M. E. Análise da produção científica sobre Hepatite B na pós-graduação de enfermagem: [revisão]. Revista Brasileira de Enfermagem: Teresina, PI, v. 61, p. 518-522, 2008.

CASTRO, M. E. B. et al. Biologia Molecular de Baculovírus e seu uso no Controle Biológico de Pragas no Brasil. Pesquisa Agropecuária Brasileira: Brasília, DF, v. 34, p. 1733-1761, Out. 1999. 
CHANG, J. H. et al. An improved baculovirus insecticide producing occlusion bodies that contain Bacillus Thuringiensis insect toxin. Journal of Invertebrate Pathology: New York, NY, v. 84, p. 30-37, Set. 2003.

FERREIRA, C.T.; SILVEIRA T.D. Hepatites virais: aspectos da epidemiologia e da prevenção.

Revista brasileira de epidemiologia: Porto Alegre, RS, v. 7, p. 473-487, Dez. 2004.

FERREIRA, R. C. et al. Prevalence of hepatitis B virus and risk factors in Brazilian noninjecting drug users. Journal of medical virology: New York, NY, v. 81, p. 602-609, Abr. 2009.

FIELDS, B. N.; KNIPE, D. M.; HOWLEY, P. M. Fields Virology. 5. ed.; Philadelphia: LippincottRaven, 2007.

FONSECA, J.C.F. Histórico das hepatites virais: [revisão]. Revista da Sociedade Brasileira de Medicina Tropical: Manaus, AM, v. 43, p. 322-330, Maio. 2010.

FUNG, J. et al. Hepatitis B Surface Antigen Seroclearance: Relationship to Hepatitis B eAntigen Seroclearance and Hepatitis B e-Antigen-Negative Hepatitis. The American journal of gastroenterology: Londres, v. 109, p. 1764-1770, Nov. 2014.

FUNK, C. J.; BRAUNAGEL, S. C.; ROHRMANN, G. F. Baculovirus structure. In: MILLER, L. K. The baculoviruses. 1. ed.; New York: Plenum Press, 1997. p. 7- 32.

GARCIA - MARUNIAK, A. G. et al. Sequence analysis of the genome of the Neodiprion sertifer nucleopolyhedrovirus. J Virology: Beltimore, MD, v. 78, p. 7036-7051, Jul. 2004.

GERLICH, W. H. Medical virology of hepatitis B: how it began and where we are now. Virology jornal: Londres, v. 10, p. 239, Jan. 2013.

GONÇALVES JUNIOR, F. L. Hepatite por Vírus B: História Natural da Infecção. In: FOCACCIA, R. Tratado de Hepatites Virais e Doenças Associadas. 3. ed.; São Paulo: Atheneu, 2013. p. 327339.

GROB, P. Hepatitis B: virus, pathogenesis and treatment. Vaccine: Guildford, Surrey, UK, v. 16, p. S11-S16, Nov. 1998.

GUIDOTTI, L. G. et al. Intracellular Inactivation of the Hepatitis B Virus by Cytotoxic T Lymphocytes. Immunity: Cambridge, MA, v. 4, p. 25-36, Jan. 1996.

GUIDOTTI, L. G. et al. Viral clearance without destruction of infected cells during acute HBV infection. Science: New York, NY, v. 284, p. 825-9, Abr. 1999.

HAAS-STAPLETON, E. J., WASHBURN, J. O., VOLKMAN, L. E. P74 mediates specific binding of Autographa californica $M$ nucleopolyhedrovirus occlusion-derived virus to primary cellular targets in the midgut epithelia of Heliothis virescens larvae. Journal of Virology: Baltimore, MD, v. 78, p. 6786-6791, Jul. 2004. 
HOLLINGER, F.B; LIANG, T.J. Hepatitis B virus. In: KNIPE, D.M, et al. Fields Virology. 4. ed.; Philadelphia: Lippincott-Raven, 2001. p. 2971-3036.

HORTON, M. H.; BURAND, J.P. Saturable attachment sites for polyhedron-derived baculovirus on insect cells and evidence for entry via direct membrane fusion. Journal of Virology: Baltimore, MD, v. 67, p.1860-1868, Abr. 1993.

HOUGHTON, M. Hepatitis C virus. In: FIELDS, B.N; KNIPE, D.M; HOWLEY, P.M. Fields Virology. 3. ed.; Philadelphia: Lippincott-Raven, 1996. p. 1035 - 1058.

ISMAIL, A. M. et al. Performance characteristics and comparison of Abbott and artus realtime systems for hepatitis B virus DNA quantification. Journal of clinical microbiology: Washington, DC, v. 49, p. 3215-21, Set. 2011.

JARVIS, D. Baculovirus expression vectors. In: MILLER, L. K. The Baculoviruses. 1. ed.; New York: Plenum Press, 1997. p. $389-431$.

Je, Y. H. Baculovirus Expression Vectors that Incorporated the Foreign into Viral Occlusion Bodies. Biotechniques: Londres, UK, v. 34, p. 81-87, Jan. 2003.

KAKIMI, K. et al. Cutting Edge: Inhibition of Hepatitis B Virus Replication by Activated NK T Cells Does Not Require Inflammatory Cell Recruitment to the Liver. The Journal of Immunology: Baltimore, MD, v. 167, p. 6701-6705, Dez. 2001.

KARRON, R.A; COLLINS, P.L. Hepatitis C Virus. In: FIELDS, B.N; KNIPE, D.M; HOWLEY, P.M. Fields Virology. 5. ed.; Philadelphia: Lippincott-Raven, 2007. p. 1527-1542.

KAWATANI, T. et al. Incidence of hepatitis virus infection and severe liver dysfunction in patients receiving chemotherapy for hematologic malignancies. European Journal of Haematology: Copenhagen, DK, v. 67, p. 45-50, Jul. 2001.

LAU, G. K. K. High hepatitis B virus (HBV) DNA viral load as the most important risk factor for HBV reactivation in patients positive for HBV surface antigen undergoing autologous hematopoietic cell transplantation. Blood: Washington, DC, v. 99, p. 2324-2330, Abr. 2002.

LEE, J. M.; AHN, S. H. Quantification of HBsAg: basic virology for clinical practice. World Journal of gastroenterology: Beijing, CN. v. 17, p. 283-289, Jan. 2011.

LEE, W. M. Hepatitis B virus infection. New England journal of medicine: Boston, MA, v. 337, p. 1733-1745, Dez. 1997.

LIANG, T. J. Hepatitis B: the virus and disease. Hepatology: Baltimore, MD, v. 49, p. S13-21, Maio. 2009. 
KAWATANI, T. et al. Incidence of hepatitis virus infection and severe liver dysfunction in patients receiving chemotherapy for hematologic malignancies. European Journal of Haematology: Copenhagen, DK, v. 67, p. 45-50, Jul. 2001.

LAU, G. K. K. High hepatitis B virus (HBV) DNA viral load as the most important risk factor for $\mathrm{HBV}$ reactivation in patients positive for HBV surface antigen undergoing autologous hematopoietic cell transplantation. Blood: Washington, DC, v. 99, p. 2324-2330, Abr. 2002.

LEE, J. M.; AHN, S. H. Quantification of HBsAg: basic virology for clinical practice. World Journal of gastroenterology: Beijing, CN. v. 17, p. 283-289, Jan. 2011.

LEE, W. M. Hepatitis B virus infection. New England journal of medicine: Boston, MA, v. 337, p. 1733-1745, Dez. 1997.

LIANG, T. J. Hepatitis B: the virus and disease. Hepatology: Baltimore, MD, v. 49, p. S13-21, Maio. 2009.

MARUYAMA, T. et al. The serology of chronic hepatitis B infection revisited. The Journal of clinical investigation: New Haven, CT, v. 91, p. 2586-95, Jun. 1993.

MATOS, M. A. D. et al. Occult hepatitis B virus infection among injecting drug users in the Central-West Region of Brazil. Memórias do Instituto Oswaldo Cruz: Rio de Janeiro, RJ, v. 108, p. 386-389, Maio 2013.

MCCLARY, H. et al. Relative Sensitivity of Hepatitis B Virus and Other Hepatotropic Viruses to the Antiviral Effects of Cytokines. Journal of Virology: Baltimore, MD, v. 74, p. 2255-2264, 1 Mar. 2000.

MELLO, F. C. A. et al. Hepatitis B virus genotypes circulating in Brazil: molecular characterization of genotype F isolates. BMC microbiology, Londres, UK, v. 7, p. 103, Nov. 2007.

MOSCARDI, F. Assessment of the application of baculoviruses for control of Lepidoptera. Annual review of entomology: Polo Alto, CA, v. 44, p. 257-289, Fev. 1999.

MURPHY, F. A. Virus Taxonomy: classification and nomenclature of viruses. 1. ed. New York: Springer-Verlag Wien, 1995. p.104-113.

OCANA, S. et al. Diagnostic strategy for occult hepatitis B virus infection. World journal of gastroenterology: Beijing, CH, v. 17, p. 1553-7, Mar. 2011.

O'REILLY, D. R.; MILLER, L. K.; LUCKOW, V. A. Baculovirus Expression Vector: A Laboratory Manual. 74. ed. New York: W. H. Freeman and Company, 1992.

REHERMANN, B. et al. Hepatitis B virus (HBV) sequence variation of cytotoxic T lymphocyte epitopes is not common in patients with chronic HBV infection. The Journal of clinical investigation: New Haven, CT, v. 96, p. 1527-34, Set. 1995. 
REHERMANN, B.; NASCIMBENI, M. Immunology of hepatitis B virus and hepatitis C virus infection. Nature reviews Immunology: Londres, UK, v. 5, p. 215-29, Mar. 2005.

RIBEIRO, B. M.; SOUZA, M. L.; KITAJIMA, E.W. Taxonomia, caracterização molecular e bioquímica de vírus de insetos. In: ALVES, S.B. Controle Microbiano de Insetos. 2. ed. Piracicaba: FEALQ, 1998. p. 481-507.

ROTHER, E. Revisão Sistemática x Revisão Narrativa. Acta Paulista de Enfermagem: São Paulo, SP. v. 20, p. 5 - 6, Abr/Jun. 2007.

SABLON, E.; SHAPIRO, F. Advances in molecular diagnosis of HBV infection and drug resistance. International journal of medical sciences: Australia, v. 2, p. 8-16, Jan. 2005.

SEEGER, C.; MASON, W. S. Hepatitis B Virus Biology. Microbiology and Molecular Biology Reviews, Washington, DC, v. 64, p. 51-68, Mar. 2000.

SILVA, C. et al. The influence of occult infection with hepatitis B virus on liver histology and response to interferon treatment in chronic hepatitis $C$ patients. The Brazilian Journal of Infectious Diseases: Campinas, SP, v. 8, p. 431-439, 2004.

SILVA, L.A. Expressão de antígenos virais fusionados a uma proteína formadora de corpos de oclusão de um vírus de inseto. 2016. 92 f. Tese (doutorado) do programa de pósgraduação em Patologia molecular da Universidade de Brasília, Brasília, 2016.

SITNIK, R.; PINHO, J. Hepatitis B virus genotypes and precore and core mutants in Brazilian patients. Journal of Clinical Microbiology: Washington, DC, v. 42, p. 2455-2460, Jun. 2004.

TATEMATSU, K. et al. A genetic variant of hepatitis B virus divergent from known human and ape genotypes isolated from a Japanese patient and provisionally assigned to new genotype J. Journal of virology: Washington, DC, v. 83, p. 10538-47, Out. 2009.

THIMME, R. et al. CD8+ T Cells Mediate Viral Clearance and Disease Pathogenesis during Acute Hepatitis B Virus Infection. Journal of Virology: Washington, DC, 77, p. 68-76, Jan. 2003.

TRAN, T. T. H.; TRINH, T. N.; ABE, K. New complex recombinant genotype of hepatitis B virus identified in Vietnam. Journal of virology: Washington, DC, v. 82, n. 11, p. 5657-63, Jun. 2008.

VAN OERS, M. M.; PIJLMAN, G. P.; VLAK, J. M. Thirty years of baculovirus--insect cell protein expression: from dark horse to mainstream technology. Journal of General Virology: Londres, UK, v. 96, p. 6-23, Jan. 2015.

ZHANG, Q; CAO, G. Genotypes, mutations, and viral load of hepatitis B virus and the risk of hepatocellular carcinoma. Hepatitis Monthly: Shanghai. v. 11, p. 86-91, Fev. 2011. 